\title{
Molecular aspects of development and regulation of endometriosis
}

\author{
Yana B Aznaurova ${ }^{1,3,5^{*}}$, Marat B Zhumataev ${ }^{1,3,5}$, Tiffany K Roberts², Alexander M Aliper ${ }^{3,5,6}$ \\ and Alex A Zhavoronkov $1,3,4$
}

\begin{abstract}
Endometriosis is a common and painful condition affecting women of reproductive age. While the underlying pathophysiology is still largely unknown, much advancement has been made in understanding the progression of the disease. In recent years, a great deal of research has focused on non-invasive diagnostic tools, such as biomarkers, as well as identification of potential therapeutic targets. In this article, we will review the etiology and cellular mechanisms associated with endometriosis as well as the current diagnostic tools and therapies. We will then discuss the more recent genomic and proteomic studies and how these data may guide development of novel diagnostics and therapeutics. The current diagnostic tools are invasive and current therapies primarily treat the symptoms of endometriosis. Optimally, the advancement of "-omic" data will facilitate the development of non-invasive diagnostic biomarkers as well as therapeutics that target the pathophysiology of the disease and halt, or even reverse, progression. However, the amount of data generated by these types of studies is vast and bioinformatics analysis, such as we present here, will be critical to identification of appropriate targets for further study.
\end{abstract}

Keywords: Endometriosis, Reproductive age, Bioinformatics analysis, Signaling pathways, Biomarkers, Therapeutic targets

\section{Background}

Endometriosis is considered to be a benign gynecological condition. However, it is extremely common, affecting up to $10 \%$ of women of reproductive age and can present with severe symptoms such as chronic pelvic pain, pain with menstruation, pain during intercourse (dyspareunia), and dysmenorrhea [1]. While the underlying pathophysiology of endometriosis remains elusive, it is known to be a hormone-dependent disease characterized by ectopic endometriotic lesions. In fact, the pain associated with the severe deep-infiltrating form of the disease is frequently due to the penetration of the muscularis propria by endometriotic lesions in the peritoneal cavity, fallopian tubes, rectosigmoid colon, and bladder [2]. Furthermore, endometriotic lesions can result in scarring of the reproductive organs causing infertility in up to $30 \%$ of women who suffer from endometriosis [3,4]. There are many theories

\footnotetext{
* Correspondence: yanaaznaurova@gmail.com

${ }^{1}$ I.M. Sechenov First Moscow State Medical University, Moscow, Russian Federation

${ }^{3}$ The First Open Institute for Regenerative Medicine for Young Scientists, Moscow, Russian Federation

Full list of author information is available at the end of the article
}

regarding the pathogenesis of endometriosis and extensive analysis of the involved signaling pathways will lay a critical foundation for the development new therapies.

\section{Epidemiology: the rise of endometriosis}

The exact prevalence of endometriosis in the population today is difficult to determine because it is asymptomatic or subclinical in the majority of cases. The prevalence has been estimated to be as low as $1 \%$ among asymptomatic women and as high as $60 \%$ in women with chronic pelvic pain $[5,6]$.

A 2012 study of a German insurance cohort found that the overall prevalence was approximately $0.8 \%$ [5]. However, this particular study was enriched for asymptomatic patients in that four age matched controls were identified for each symptomatic patient. This is contrary to the vast majority of studies which are enriched for symptomatic patients, such as a 2013 study in which $62 \%$ of adolescent girls being followed for either chronic pelvic pain or dysmenorrhea were diagnosed with endometriosis [6]. Such disparate reports emphasize the complexity of determining, with any certainty, either the prevalence or incidence of this disease. 
While some of the more recent studies have suggested that the prevalence of endometriosis may actually be lower than was previously thought, there has been a perceived increase in the incidence of endometriosis in the past several decades [5,7]. This perception may be due to a combination of increased awareness and better diagnosis.

\section{Risk factors}

Age

As a hormone-dependent disease of continued endometrial growth, endometriosis is predominantly a disease of women of reproductive age. Endometriosis is rarely found in pre-adolescents with an incidence of only $0.05 \%$ in symptomatic patients. In women of reproductive age, the highest incidence was found in women aged 35-44 $(0.4 \%)$ (relative risk $(R R)=6.3)$, regardless of symptoms [5]. This is in comparison to women aged 25-34 ( RR - 4.0) and 45-54 (RR - 4.5), respectively [5]. However, endometriosis is also frequently diagnosed in symptomatic post-menopausal women (incidence of $2.55 \%$ ) [8]. It is possible that an increase in endometriosis can be attributed, in part, to the aging of the global population.

\section{Lifestyle}

\section{- Reduced pregnancy rate}

The theory that drastically decreased pregnancy rates as a direct result of the modern woman's lifestyle, including the availability of contraceptives, contributes to an increased incidence of endometriosis is well established [9-11]. In the absence of frequent pregnancy, the endometrium continually builds-up and then sheds under the control of hormonal signaling. It is thought that the cycling of the endometrium with more frequent menses can lead to endometriosis. Evidence that symptoms of endometriosis resolve during pregnancy has led to frequent treatment with the use of oral contraceptive pills (OCPs) to induce "pseudopregnancy" [12,13]. Even though most women still experience monthly menses while taking OCPs, the hormonal levels simulate pregnancy thereby inhibiting ovulation but also decreasing endometrial build-up and menstrual flow as well as improving endometriosis symptoms.

\section{- Shift work}

Menstrual cycle and endometriosis are both driven by circulating estrogen levels [14]. There is evidence to suggest that estrogen levels in women of reproductive age follow a circadian rhythm in addition to the monthly ovarian rhythm and, therefore, may be vulnerable to circadian disturbance $[15,16]$. In fact, night shift work has been shown to affect estrogen secretion and has been associated with menstrual disruption as well as increased risk of endometriosis $[17,18]$. One study found that any night shift work at all increased the risk of endometriosis by $50 \%$ [14].

\section{Toxins}

2,3,7,8-Tetrachlorodibenzo- $p$-dioxin (TCDD) and structurally related polyhalogenated aromatic hydrocarbon chemicals (PHAHs) are common environmental contaminants found globally. TCDD and dioxin-like PHAHs are classified as "dioxins" and are associated with a spectrum of toxic effects on the reproductive, immune, and endocrine systems [19]. Additionally, polychlorinated biphenyls (PCBs) contribute to the toxicity of PHAHs including disruption of estrogen activity [20,21].

Dioxins are released into the air as a product of various industrial processes and, therefore, exposure has steadily increased over the last century [22]. The compounds accumulate in the environment and people are exposed through the consumption of animal products as the compounds bioaccumulate in fatty tissues [23]. Food sources account for $93 \%$ of dioxin exposure levels in the US population, although inhalation, soil, and water sources may also play a role [24].

A clear relationship between dioxin exposure and the development of endometriosis has been well established in both rodent and primate models [25-29]. However, a causal relationship between the two has not yet been verified in humans though there is evidence to support it. For example, development of ectopic lesions is induced by dioxin exposure in a rodent model using human endometrium [30,31]. Moreover, studies from around the globe have linked an increased risk of endometriosis with elevated concentrations of dioxin in patient serum [32-35].

\section{Autoimmunity}

Endometriosis is understood to be an inflammatory disease process, which suggests a role for the immune system [36]. It has been postulated that one mechanism for the development of ectopic endometrial lesions is a defective immune response, which fails to clear the implants from the peritoneal surface [36,37]. In fact, immune deficits fulfilling most of the basic criteria for autoimmune disease have been described in endometriosis, including polyclonal B-cell activation, abnormalities in $\mathrm{T}$ - and B-cell function, tissue damage, and multi-organ involvement [38,39]. Furthermore, allergies, hypothyroidism, inflammatory bowel disease, and fibromyalgia are among a number of autoimmune conditions known to be associated with endometriosis [40,41]. However; it remains unclear whether these comorbidities 
may be a cause or an effect of the disease. Perhaps the most convincing evidence that endometriosis may have an autoimmune component is the presence of circulating antibodies towards ovarian and endometrial antigens [42-45]. These auto-antibodies are likely to play a role in both the pathogenesis of endometriosis as well as pregnancy loss in patients with the disease, but further study is needed to firmly establish these links $[43,44]$.

\section{Etiology}

\section{Retrograde menstruation theory}

Approximately $75-90 \%$ of women experience some retrograde intra-abdominal bleeding during menses [46]. The development of endometriosis has been linked to exposure of the pelvic peritoneum to the blood products and cellular debris contained within menstrual fluids, which would normally be confined to the pelvis $[46,47]$. Furthermore, menstrual fluid also contains some abnormal stem cells, which have been shown to have increased implantation and angiogenic capabilities and can form ectopic tissue lesions in animal models $[47,48]$.

\section{Coelomic metaplasia}

While retrograde menstruation is the most widely accepted mechanism, it cannot explain rare cases of endometriosis in the absence of a functioning uterus. The coelomic metaplasia theory proposes that endometriosis develops as a result of transformation of mesothelial cells on the ovary to endometriotic gland cells $[49,50]$. In fact, mesothelial inclusions have been found to be associated with endometriosis in the ovaries, fallopian tube, and pelvic wall [51]. Rare cases of endometriosis described among men, pubertal and adolescent girls, and distant endometriosis in the thoracic cavity support this particular theory [52-54]. Furthermore, an in vitro experimental model of human endometriosis demonstrated that ectopic lesions can result from metaplasia of the ovarian surface epithelium [55].

\section{Lymphovascular metastasis}

The theory of lymphatic and hematogenous spread has long been considered to explain remote occurrence of the disease as well. According to this theory, exfoliated endometrial cells are swept into the venous drainage of the uterus, with subsequent deposition possible anywhere in the body. The theory is supported by the presence of endometriosis in the thoracic cavity and other distant sites outside pelvis as well as detection of endometrial tissue in the uterine vessels in patients with adenomyosis [56]. Lymphovascular metastasis remains a speculative explanation and, while possibly occurring during the development of endometriosis, is not likely to be the primary mechanism as cases of pulmonary and thoracic endometriosis are rare $[57,58]$.

\section{Embryonic rest theory}

During embryogenesis, some endometrial cells that should grow in the uterus develop in the abdomen instead [59]. These cells would then be activated in puberty under the effects of estrogen and progesterone. Embryogenesis is controlled and directed by a sophisticated, but still incompletely understood, fetal system. This fetal developmental control system may be the fetal analog of the adult immune system. Abnormalities of the fetal development control system may be preserved into adult life, giving rise to detectable abnormalities of the adult immune system $[60,61]$. The degree of residual abnormality of the adult immune system may control the aggressiveness of the endometriosis that develops, with the result that some patients may develop invasive disease or adhesions, while most do not.

\section{Smooth muscle cells}

Endometrial stromal cells (ESCs) are the most prevalent cell type in endometriotic lesions. However, smooth muscle cells (SMCs) are also frequently found and have been reported in peritoneal, ovarian, and deep-infiltrating endometriosis [62-65]. Peritoneal SMCs express oxytocin receptors (OTRs), estrogen receptors (ERs), and progesterone receptors (PRs), which are required components of uterine myometrial cells [66]. In contrast, the ability of SMCs to produce contractions has not been demonstrated. It is plausible that peritoneal SM contractions could stimulate peritoneal nociceptors leading to the generation of endometriosis-associated pain [67]. However, whether these SMCs are derived from basal stem cells or reactivated coelomic epithelial cells is still unclear [68].

\section{Altered immune response}

Macrophages are an integral component of the mononuclear phagocyte system (MPS). They are derived from bone marrow progenitors that enter the circulation as monocytes. After reaching peripheral tissues, they reside as macrophages or antigen-presenting cells, including dendritic cells (DCs). The MPS performs both pathogen eliminating and homeostasis support functions $[69,70]$. In mouse models, in the absence of macrophages, endometriotic tissue retains the ability to adhere to the peritoneal layer [71]. However, the angiogenic properties were inhibited and endometriotic lesions failed to grow. Infiltrating macrophages have been reported as a consistent feature of endometriotic lesion development in humans. Independent studies have indicated that they are activated by sequence of signals generated within ectopic endometrial lesions or because of the lack of antiinflammatory hormone-regulated signals in ectopic sites [72-76]. Macrophages are also known to be the source of several chemokines that are involved in endometriosis [71]. However distinct molecular mechanisms that 
will be useful for diagnostics and treatment remain to be defined.

\section{Cellular mechanisms}

Endometriosis has long been understood to be a disease of uncontrolled and aberrant growth of endometrial tissue. However, the cellular and molecular mechanisms that are disrupted in this disease remain ill defined. The cell signaling pathways involved can be divided into those involved in proliferation and apoptosis, adhesion and invasion, angiogenesis, and immune function.

\section{Proliferation and apoptosis}

The mechanisms regulating endometrial cell proliferation are primarily controlled by interactions between the sex steroids and their receptors [77]. Cyclical regulation of cellular proliferation by sex hormones is lost in endometriotic tissue. It is well-known, that alterations in cell cycle molecules such as cyclin and cyclin-dependent kinases are hormone dependent [78]. For example, FOXO1A, a transcription factor involved in cell cycle control and apoptosis, is regulated by progesterone and its expression is significantly reduced in the endometrial tissue of women with endometriosis. Another cell cycle regulatory protein, ErbB-2 (TOB1) is also known to be downregulated in women with endometriosis, which may be the result of increased interleukin (IL)- $1 \beta$ levels.

Growth factors also contribute to the increased proliferative potential of cells derived from endometriotic lesions. In fact, epidermal growth factor (EGF) is confirmed to stimulate proliferative activity in these cells $[79,80]$. Mitogen inducible gene 6 (MIG6) is a negative regulator of EGF signaling. MIG6 is down-regulated in women with endometriosis and may, therefore, contribute to unmitigated growth of endometrial cells. Midkine (MK) is a member of the heparin-binding growth factor family that is over-expressed in the ectopic endometrium, which has been implicated in proliferation, migration, angiogenesis, and fibrinolysis [81] [Figure 1].

The recurrent bleeding that is a hallmark feature of endometriosis leads to continual thrombin generation, which can subsequently stimulate proliferation of endometriotic cells via protease-activated receptor 1 (PAR1) [77]. PAR1 downstream signaling induces expression of monocyte chemoattractant protein-1 (MCP1), tissue necrosis factor alpha (TNF $\alpha$ ), interleukins (IL), cyclooxygenase-2 (COX-2), matrix metalloproteinases (MMP), hepatocyte growth factor (HGF), and tissue factor (TF) [77]. Inhibition of COX-2 effectively reduces endometriotic epithelial cell proliferation [82]. Furthermore, TNF $\alpha$, various interleukins, and HGF, which are known to be significantly elevated in the peritoneal fluid of women with endometriosis, also contribute to proliferation of endometriotic cells $[83,84]$.
Leptin is primarily known as the protein released by fat cells. However, leptin is also found at elevated levels in the peritoneal fluid and serum of patients with endometriosis [85]. Leptin expression can be stimulated by pro-inflammatory cytokines such as TNF $\alpha$ and IL-1 and can, in turn, stimulate proliferation of ectopic endometriotic cells $[77,85]$. Retinoic acid (Vitamin A), on the other hand, is known to protect against endometriosis [86]. However, the retinoic acid catabolic enzyme CYP26A1, is a progesterone responsive gene that is upregulated in women with endometriosis [87]. By inactivating retinoic acid, CYP26A1 contributes to establishment of endometriotic lesions.

The Aryl Hydrocarbon Receptor (AHR) transcription factor is recognized as the culprit for most toxic responses observed after exposure to PAH (Polycyclic aromatic hydrocarbons), dioxins, and PCBs. AHR can affect cellular signaling through interactions with various regulatory and signaling proteins, including those mediated by the estrogen receptor (ESR) and NF-kB (nuclear factor of kappa light polypeptide gene enhancer in $\mathrm{B}$ cells) [88]. AHR activation leads to decreases in both the number of ESRs and ESR responsiveness, as well as increases in ESR metabolism. Activated AHR complexes associate directly with ESR- $\alpha$ and $-\beta$ in the absence of estrogen resulting in transcriptional activation of canonically estrogen-dependent genes. By contrast, in the presence of estrogen, ligand-bound AHR exhibits anti-estrogenic effects by suppressing estrogen-bound ESR-mediated DNA binding. AHR may also be involved in cell-cycle regulation through growth factor signaling, cell-cycle arrest, and apoptosis.

In addition to increased proliferation, the cells that comprise endometriotic lesions are thought to have defects in apoptotic signaling pathways. AHR also interacts with nuclear factor kappa-B (NF-kB) signaling pathways [89-91]. The pleiotropic transcription factor, NF- $k B$ has been identified to protect cells from apoptosis. The protein is constitutively active in endometriotic cells and its activation by lipopolysaccharide (LPS) can induce proliferation of endometriotic cells [92]. B-cell lymphoma/ leukemia-2 (Bcl-2) is a well-known anti-apoptotic signaling protein. In normal endometrium, $\mathrm{Bcl}-2$ demonstrates cyclical expression decreasing during the menstrual and late proliferative phases, indicating hormonal regulation. However, this regulation is lost in endometriosis [77]. Conversely, expression of the pro-apoptotic protein Fas is unchanged while its ligand, FasL, is upregulated in endometriotic tissue as well as the peritoneal fluid of women with endometriosis [93,94]. There is evidence to suggest that macrophage derived growth factors, including platelet-derived growth factor and transforming growth factor beta (TGF- $\beta$ ), may stimulate Fas mediated apoptosis of immune cells, which may contribute 


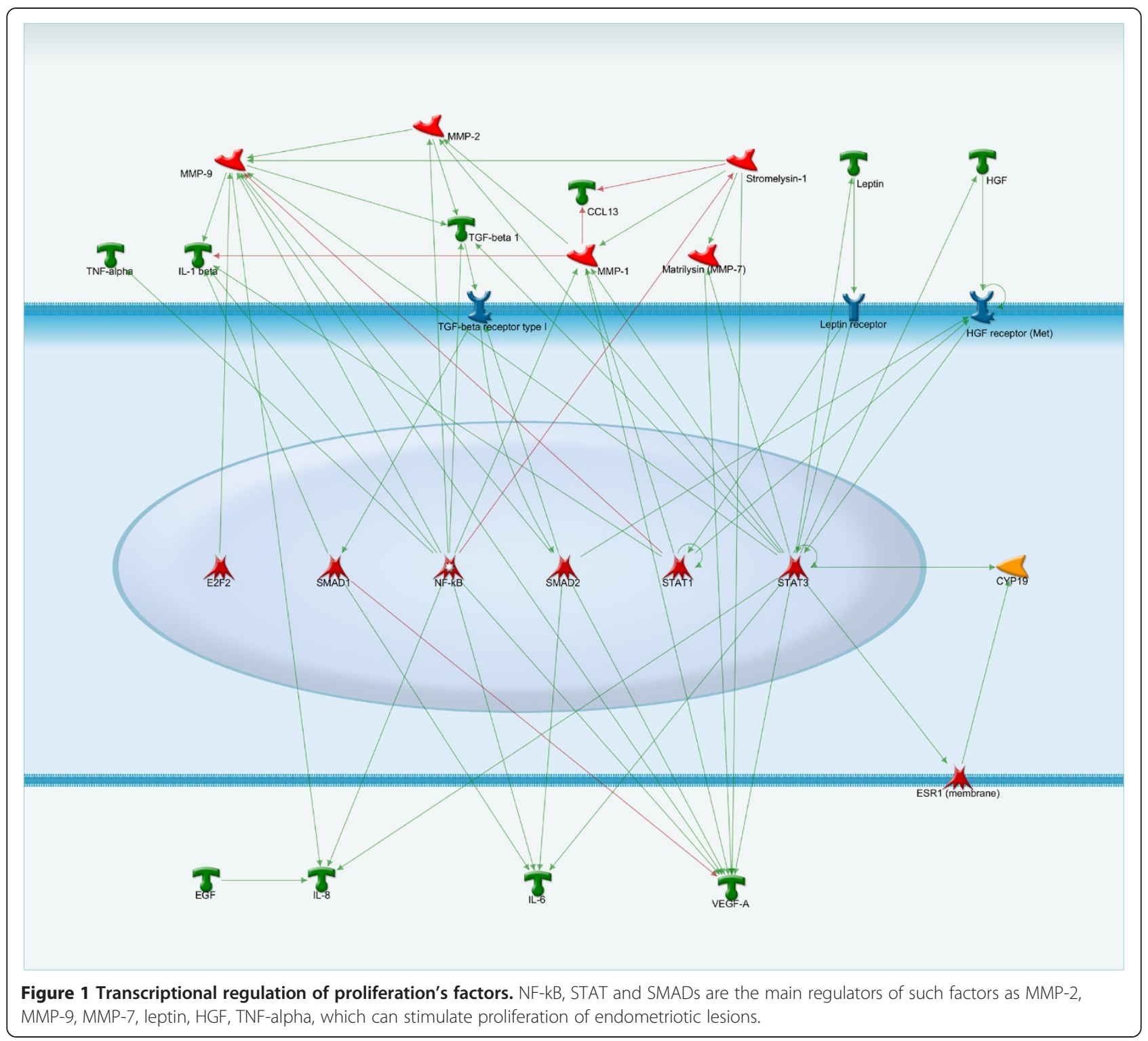

to an immune-privileged environment for endometriotic cell survival [94]. Furthermore, upregulated expression of survivin, decreased terminal effector caspases and DNA fragmentation factor 45 in endometriotic tissues may be a reflection of resistance against apoptosis at ectopic sites [77].

Watanabe et al. demonstrated that survivin plays a critical role in susceptibility of endometrial stromal cells (ESCs) to apoptosis [95]. Survivin treatment of ESCs leads to a reduction of apoptosis inhibiting proteins, such as cIAP-1, XIAP, and survivin as well as an increase of apoptotic cells [95].

ESCs have been shown to be resistant to IFN- $\gamma$ treatment, which inhibits the proliferation and apoptosis of EuSCs and NESC. Although the precise mechanism of IFN- $\gamma$ resistance is unknown, the presence of IFN- $\gamma$ receptor in ECSC suggests that there is dysregulation of subsequent intracellular signaling pathways in these cells [96].

\section{Adhesion and invasion}

In order for endometriotic lesions to occur, the cells must invade and implant in distant locations. Increasingly, studies are noting roles for adhesions molecules and growth factors in this process. Cells derived from endometriotic lesions have increased adhesive capacity to various components of the extra cellular matrix (ECM) including collagen type IV, laminin, vitronectin, and fibronectin, whereas normal endometrium is more specific $[77,97]$. In fact, in the early stages of endometriosis, attachment seems to be due to ECM degradation that could play a key role in initiation of endometriosis [98]. 
Integrins are a family of cell-cell adhesion molecules that promote cell attachment to the ECM proteins thereby sustaining cell migration and invasion [99]. The $\beta-1$ integrins and E-cadherin are both found in the endometrium [99]. Aberrant expression of E-cadherin, $\beta$-catenin, and integrins has been reported in endometriosis. $\beta$-catenin plays a role in cell-to-cell adhesion and intracellular signaling binding to intracellular E-cadherin and connecting E-cadherin to the cytoskeleton of the cell [100]. The E-cadherin- $\beta$-catenin complex plays a crucial role in epithelial cell-cell adhesion and in the maintenance of tissue architecture [101]. Aberrant expression of cadherins and integrins is involved in initiation and progression of human tumors [102]. In the case of endometriosis, there are controversial reports about expression levels of these adhesion proteins.

Poncelet et al. have reported reduced expression of E-cadherin in ESCs [103]. Loss of E-cadherin expression may be related to the local aggressiveness and invasiveness of peritoneal endometriotic lesions [101]. Indeed, Gaetje et al. found in an in vitro study using peritoneal endometriotic biopsies that E-cadherin positive cells were devoid of invasive capacities whereas E-cadherin negative cells were invasive [104]. Conversely, Ueda at al. did not find altered expression of E-cadherins in peritoneal endometriotic lesions compared to eutopic endometrium [102]. This data are supported by other studies, which have also found high E-cadherin expression in endometriotic lesions, with no difference compared to proliferative endometrium [101,105]. E-cadherin expression in endometrial cells has been reported to be constant throughout the menstrual cycle $[105,106]$. However, another study found that E-cadherin mRNA was significantly lower at the proliferative phase than at the secretory phase [107]. Thus, E-cadherin expression can probably be affected by menstrual cycle phase and stage of endometriosis. Hereby, E-cadherin expression patterns in endometriotic tissues are contradictory and the role of E-cadherin in the development and progression of endometriosis is still unclear.

In recent studies, $\beta$-catenin has been shown to be down-regulated in endometrioid carcinoma and reduced $\beta$-catenin expression could be involved in the pathogenesis of endometriosis contributing to its invasive character. Others have suggested that increased expression of $\beta$-catenin and activation of $\mathrm{Wnt} / \beta$-catenin complex may be a molecular mechanism of fibrosis in endometriosis [101,108,109].

Interestingly, endometriosis showed decreased $\beta$-catenin expression compared with endometrioid carcinoma. This implies that different alterations in the E-cadherin- $\beta$ catenin complex contribute to the pathogenesis of endometriosis and endometrioid carcinoma. It seems logical that different changes in epithelial adhesion molecules participate in the initiation and/or disease progression of a benign as opposed to a malignant disease [99].

Wnt/ $\beta$-catenin complex regulates stem cell pluripotency and cell development, integrating signals from other pathways, such as TGF- $\beta$ and FGF (Fibroblast growth factor), and targeting genes involved in cell migration and proliferation [110]. In particular, TGF- $\beta$ has been reported to be involved in the pathogenesis of endometriosis, playing a critical role in migration and proliferation of fibroblasts to develop endometriotic lesions [108].

$\mathrm{P}$-cadherin is the predominant cadherin subtype present in the human peritoneum and P-cadherin mRNA has been found to be significantly increased in peritoneal endometriotic lesions compared with eutopic endometrium, suggesting that $\mathrm{P}$-cadherin may be involved in mediating endometrial-peritoneal cell interactions in the development of endometriosis [111].

Integrins mediate adhesion of cells to ECM components, such as collagen types I and IV, fibronectin, and laminin. Integrins are a large family of transmembrane glycoproteins that have a dimeric structure of $\alpha$ and $\beta$ subunits and act as receptors for ECM components. There are several studies investigating the aberrant expression of integrins in endometriotic cells and their role in the invasion and attachment of ESCs to different components of the ECM [99]. Integrins $\beta 1$ and $\beta 5$ were present in endometriotic lesions in a nude mouse model and shown to be of peritoneal origin [112]. Higher levels integrin of $\alpha 1, \alpha 2, \alpha v, \beta 1$, and $\beta 3$ protein expression were observed in ESCs than in (normal eutopic endometrial cells) NESCs. On the other hand, the levels of integrin $\alpha 3$ and $\alpha \mathrm{L}$ proteins were lower in ESCs than in NESCs [61]. Integrin $\alpha 3 \beta 1$ is weakly expressed in menstrual endometrium and integrin $\alpha 6 \beta 1$ is strongly expressed, both have been characterized as the principal laminin receptors. Blockage of the $\beta 6$ subunit by a specific antibody has led to a significant reduction of adhesion of ESCs to laminin and a smaller reduction to other ECM components [113]. Adhesion to fibronectin is mediated by the $\alpha 4 \beta 1, \alpha 5 \beta 1$ and $\alpha v \beta 3$ integrins. Blockage of the $\beta 1$ subunit and RGD (Arg-Gly-Asp) antibodies that are involved in $\alpha 5 \beta 1$ and $\alpha v \beta 3$ integrin function have not prevented adhesion of ESCs to fibronectin. Blocking of collagen receptors $\alpha 1 \beta 1, \alpha 2 \beta 1, \alpha 3 \beta 1$ did not reduce adhesion of menstrual endometrial cells to collagen. These data suggest that $\alpha 6 \beta 1$ could play a key role in early phases of the development of the endometriosis [113]. Previous studies investigating the role of integrins in menstrual endometrium attachment have not shown the complete inhibition of adhesion to ECM components that suggest other mechanisms to be involved [113].

Osteopontin (OPN) is a glycoprotein involved in cell adhesion and migration by binding to integrins [114]. 
OPN levels are increased in both the blood and ectopic endometrium of women with endometriosis [114]. OPN is also speculated to influence migration and angiogenesis by regulating CD133+, also known as prominin-1, progenitor cells [114]. The migration of these progenitor cells is thought to contribute to the establishment of distant endometriotic lesions.

Octamer-binding transcription factor 4 (OCT4) is a pluripotent factor that has been reported to be overexpressed in endometrial lesions $[115,116]$. The expression of OCT4 may contribute to the pathology of ectopic endometrial growth by stimulating the migration activity of endometrial cells [115].

Matrix Metalloproteinases (MMPs) also contribute to cell migration via break down of ECM components and subsequent tissue remodeling. MMP-1, -2, $-3,-7$, and -9 are upregulated in endometriosis and their expression is induced by cytokines such as IL-1, IL-8, and TNF- $\alpha[117,118]$. Furthermore, expression of tissue inhibitor of metalloproteinase-1 (TIMP-1) is decreased in the peritoneal fluid of women with endometriosis [119]. TIMPs have been shown to control endometriotic cell migration induced by MMPs, suggesting that its downregulation is a major factor in the pathophysiology of endometriosis.

\section{Angiogenesis}

Just as observed for tumor growth, angiogenesis of lesions is essential for endometriotic cell survival and development. The two main regulators of angiogenesis are vascular endothelial growth factors (VEGF) and angiopoietins [120] [Figure 2]. VEGF is a key regulator of both physiological and pathological angiogenesis. VEGF is significantly increased in the peripheral blood, peritoneal fluid, and endometrium of patients with endometriosis and its expression is known to be stimulated by a variety of cytokines, including IL-1 [121]. Inhibition of VEGF has been shown to lead to a significant decrease in the number of endometriotic lesions [122]. Angiopoeitin-1 (Ang-1) and Ang-2 are both increased in the endometrium of patients with endometriosis [120,123]. Ang-1 stimulates new vessel formation and Ang-2 can loosen cell-cell and cell-ECM contacts resulting in vessel remodeling.

Glycodelin is an endometrium-derived protein known for its angiogenic, immunosuppressive, and contraceptive effects. Glycodelin is thought to be involved in both the development of endometriosis and the infertility associated with the disease [124].

Glycodelin produced in the glandular epithelium of secretory endometrium and is shed from endometriotic lesions into the peritoneal fluid and serum.

These findings indicate that proangiogenic factors have pivotal roles in the pathogenesis of endometriosis [125,126].

\section{Altered immune function}

Some theories suggest that the immune system must be at least partially compromised to allow the development of ectopic endometriotic lesions. Macrophages play an especially important role being the predominant leukocytes found in the peritoneal fluid of women with endometriosis [71,127]. They have been shown to be involved in ectopic endometrial cell adhesion, implantation, and growth. Moreover, the secretory products of macrophages are also significantly increased in both the peritoneal fluid of patients with endometriosis as well as in the endometriotic lesions.

One of the major secretory products of macrophages is TGF- $\beta$, which is known to play a role in increasing the rate of post-surgical adhesion formation suggesting that it may also play a role in endometriotic cell adhesion [77]. IL-1 is a macrophage derived cytokine that can induce expression of COX-2 and IL-8, thereby likely playing a role in proliferation, migration, as well as angiogenesis of endometriotic lesions [83]. Many of the genes involved in endometriosis are implicated in aging [128]. HGF is also upregulated in endometriotic lesions. HGF can be upregulated by LPS-stimulated macrophages in endometriotic lesions and subsequently enhance proliferation of endometriotic cells [129]. Macrophages are also potential sources of the increased VEGF in patients with endometriosis. Studies in mouse models demonstrate that after implantation of uterine tissues into the peritoneum, macrophages are activated and VEGF is secreted in response to TNF- $\alpha$ and IL-6 [127].

Prostaglandin-E2 (PGE2) is another secretory product of macrophages that is also produced by ectopic endometrial cells $[130,131]$. PGE2 plays multiple roles in the pathophysiology of endometriosis via signaling through four receptors. Firstly, PGE2 increases estrogen synthesis by up regulating steroidogenic acute regulatory protein (StAR) and aromatase [130]. PGE2 in combination with IL-4 may enhance estrogen production in endometriotic tissues, implying an elaborate mechanism by which the Th2 immune response augments inflammation-dependent progression of the disease [131]. Furthermore, through its effect on estrogen and up regulation of VEGF, PGE2 affects leukocyte populations and promotes angiogenesis. It also inhibits apoptosis and up regulates fibroblast growth factor-9 (FGF-9) to promote cell proliferation.

Lastly, macrophage migration inhibitory factor (MIF) is a cytokine that is a major immune regulator as well as a potent angiogenic and tissue remodeling factor. MIF is significantly increased in endometriotic lesions and is likely upregulated by IL-1 in this context [132].

Natural Killer (NK) cells are a major component of immune surveillance and NK cell activity in the peritoneal fluid can suppress formation of ectopic lesions [133]. Therefore, it follows that their activity is decreased in 


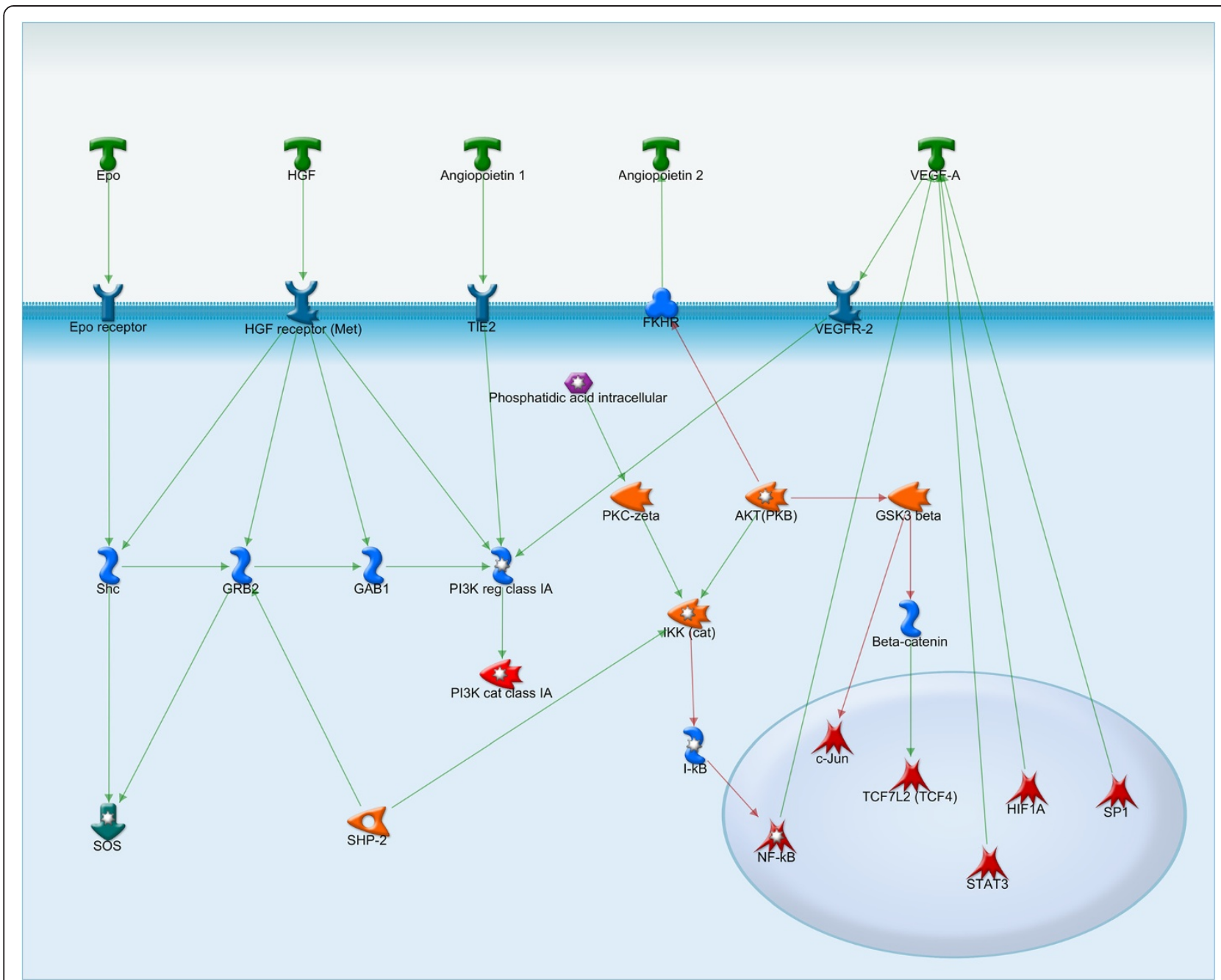

Figure 2 VEGF and angiopoietin - two main regulators of angiogenesis. Angiogenesis of lesions is essential for endometriotic cell survival and development. Signaling pathways of VEGF and angiopoietin intersect at PI3K.

the peritoneal fluid of women with endometriosis [134]. Soluble intercellular adhesion molecule-1 (sICAM-1), one of the major adhesion molecules that inhibits natural killer cell-mediated cytotoxicity, is involved in the implantation and development of endometriotic lesions $[135,136]$. Studies have confirmed changes in sICAM-1 levels in women with endometriosis compared with controls [137,138].

Endometriosis is an inflammatory disease associated with abnormal T-cell function. IL-4, a cytokine produced by helper T-cells (Th) is significantly upregulated in endometriotic lesions and can stimulate the proliferation of endometriotic cells [139]. Th17 cells are also enriched in the peritoneal fluid of women with endometriosis as well as the ectopic endometrium. IL-17 has been shown to stimulate IL- 8 and COX-2 expression thereby enhancing proliferation and migration of endometriotic cells [140].
Monocyte chemotactic protein-1 (MCP-1) is a member of the small inducible gene family, which plays a role in the recruitment of monocytes to sites of injury and inflammation [141]. Levels of MCP-1 are increased in the peritoneal fluid and serum of women with endometriosis, particularly in patients with early disease [142].

Lastly, mast cells are the major effectors of allergic responses and have been found in increased numbers in ectopic endometrium [77]. Mast cells are likely associated with the fibrosis and adhesion of the lesions. Based on rat models, there is a strong correlation between endometriosis and allergies [77].

Perhaps the most important component of immune dysregulation in endometriosis is mediated by the major histocompatibility complex (MHC). The MHC, also known as Human Leukocyte Antigens (HLA), are cell surface proteins that mediate interactions between immune responsive cells. Aberrant expression of both Class I and II MHC 
antigens in endometriotic lesions inhibits the cytotoxic activity of NK cells $[143,144]$. Some studies have suggested that the class I antigens HLA-B*07 and B*46 are associated with the development of endometriosis, whereas HLA-B*48 may offer a protective effect $[145,146]$. Additionally, the class II HLA-DR antigens are aberrantly expressed in glandular cells of endometrium in endometriosis and adenomyosis and are thought to be involved in various immunological abnormalities [147,148]. Nonclassical HLA-G proteins have been suggested to be expressed on ectopic endometriotic cells and to play a critical role in the development of endometriosis though the suppression of NK function $[149,150]$. However, other studies have reported that HLA-G is not expressed by endometrial cells at all [151].

Despite what is known about altered MHC expression, it is equally plausible that abnormalities in NK receptors could lay the basis of altered immune response in endometriosis. For example, polymorphisms in killer cell immunoglobulin-like receptors (KIRs) may be associated with susceptibility for endometriosis [152].

\section{MicroRNA}

MicroRNAs (miRNAs) are naturally occurring posttranscriptional regulatory molecules that potentially play a role in endometriotic lesion development [Figure 3]. In one study, 22 endometriosis-associated miRNAs were identified by microarray analysis in paired ectopic and eutopic endometrial tissues [153]. Of these, 14 were found to be up-regulated (miR-145, miR-143, miR-99a, miR-99b, miR-126, miR-100, miR-125b, miR-150, miR125a, miR-223, miR-194, miR-365, miR-29c and miR-1) and 8 down-regulated (miR-200a, miR-141, miR-200b, miR-142-3p, miR-424, miR-34c, miR-20a and miR-196b) miRNAs [153]. Functional analysis indicated that 673 miRNA targets constitute molecular pathways involved in the development of endometriosis, including c-Jun, CREB-binding protein, protein kinase B (Akt), and cyclin D1 (CCND1) signaling [141]. Another study found 10 microRNAs that were up-regulated (miR-202, 193a3p, 29c, 708, 509-3-5p, 574-3p, 193a-5p, 485-3p, 100, and 720 ) and 12 that were down-regulated (miR-504, 141, 429, 203, 10a, 200b, 873, 200c, 200a, 449b, 375, and $34 \mathrm{c}-5 \mathrm{p})$ in endometriosis compared with normal endometrium [154].

A number of miRNAs are regulated by $17 \beta$ estradiol and progesterone in the endometrial epithelial and stromal cells, including miR-20a, miR-21, miR-23, miR-26a, miR-18a, miR-181a, miR-206, and miR-142-5p. These miRNAs have been predicted to target the expression of a large number of genes, including transforming growth factor $\beta$ (TGF- $\beta$ ), TGF- $\beta$ receptors, ERs, PRs, and CYP19A1 (aromatase), many of which are known to play critical roles in endometrial activities [155].
Additional studies have explored individual miRNAs in eutopic endometrium from women with endometriosis. Compared with healthy controls, endometrium from women with endometriosis is characterized by over-expression of miR-135a in the proliferative phase and $\mathrm{miR}-135 \mathrm{~b}$ in the proliferative and secretory phases [156]. These miRNAs were predicted and validated to target HOXA10, a key mediator of endometrial receptivity, the expression of which was simultaneously repressed in the endometrium of women with endometriosis [157]. Transfection of ESCs with miR-135a/b or miR-135a/b inhibitors resulted in altered expression of HOXA10 mRNA and protein and this may suppress endometrial receptivity in endometriosis [157].

Transfection of ESCs with miR-199a repressed IкB kinase/NFKB signaling and inhibited IL-8 secretion. Therefore, the low expression levels of miR-199a in ESCs from women with endometriosis would be expected to up-regulate these inflammatory mediators and result in decreased endometrial receptivity and implantation defects [158].

Decreased miR-20a and miR-200b may contribute to the up-regulation of CREB binding protein (CREBBP) mRNAs in endometriosis [159]. CREBBP is a co-activator of hypoxia inducible transcription factor 1a (HIF1a), a hypoxia induced and pro-angiogenic transcription factor. CREBBP/HIF1a activities are likely to be increased in ectopic endometriotic lesions due to loss of transcript suppression by downregulation of miR-20a and miR-200b. Reduced repression of HIF1a mRNA translation by miR$20 \mathrm{a}$ is consistent with the elevated HIF1a mRNA levels seen in endometriotic lesions. CREBBP was also central in one of our miRNA regulated pathway networks associated with angiogenesis in endometriosis.

Both HIFa and $\mathrm{NF}_{\kappa} \mathrm{B}$ can be activated by elevated levels of IL-1 $\beta$ and TNF $\alpha$ in endometriosis. This process can lead to enhanced COX-2 transcription [160]. COX-2 participates in a positive feed forward loop that enhances aromatase activity and local estradiol production in endometriotic lesions, thereby promoting a proliferative local hormonal environment. COX-2 translation is known to be suppressed by miR-199a and miR-16 and both of these miRNAs were down-regulated in endometriosis $[155,161]$.

Apoptotic resistance is mediated by BCL2, leading to enhanced survival of stressed endometrial cells in endometriosis. BCL2 is targeted by miR-15b/16 and the reduced expression of these miRNAs may contribute to increased activity of this anti-apoptotic protein in endometriosis [162]. Furthermore, cell proliferation is promoted by the cell cycle regulator insulin receptor substrate-1 (IRS1). Two highly up-regulated miRNAs in endometriosis, miR-126 and miR-145, target this mitogenic protein and may inhibit endometrial cell proliferation 


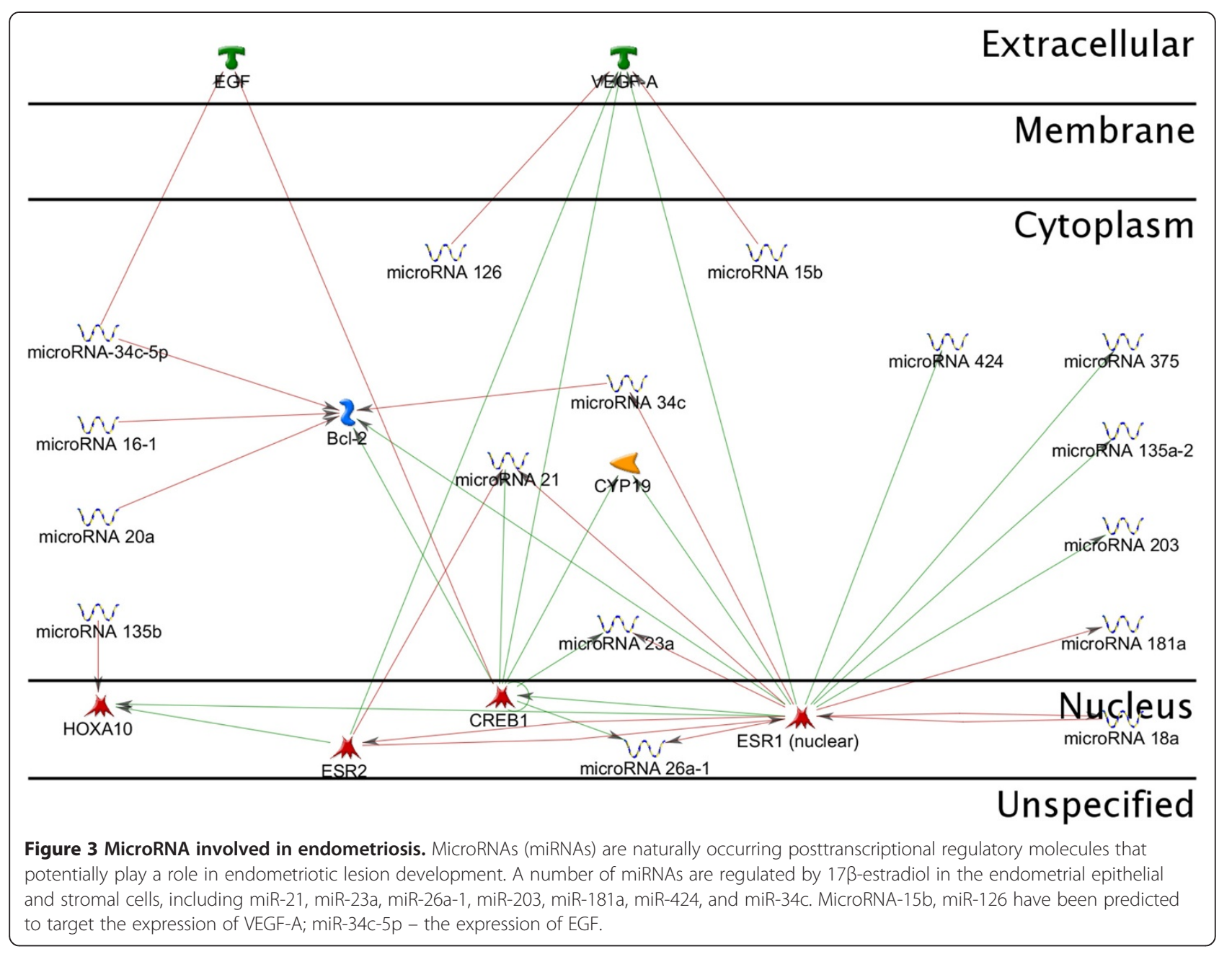

[153]. The low levels of miR-20a, miR-221 and miR-222 seen in endometriotic tissues may ease post-transcriptional suppression of their mRNA targets, which include the cell cycle repressors cyclin-dependent kinase inhibitors CDKN1A/p21, CDKN1B (p27), and CDKN1C (p57). High miR-15b/16, miR-143, miR-145 and low miR-20a, miR-221 and miR-222 expression are consistent with repressed cell proliferation and enhanced cell survival in endometriosis [163].

Endometriotic lesion development has been associated with an aberrant expression of ECM proteins. Upregulation of miR-29c in endometriotic tissue may control the ECM production that is integral to endometriotic lesion development [153]. Precise organization of the ECM scaffold may be crucial for the correct placement of developing glands and stroma in remodeling tissues and miRNAs may contribute by fine tuning this process.

In endothelial cells, miR-126 enhances VEGF and FGF signaling, leading to neoangiogenesis and the development of mature vasculature [164]. miR-126 is embedded in the EGF-like-domain, multiple 7 (EGFL7) gene and both of these transcripts are highly up-regulated in ectopic versus eutopic endometrium, which is indicative of co-transcription $[153,165]$. EGFL7 enhances the effect of miR-126 by inducing endothelial cell migration during neovascularization [166].

\section{Screening and diagnostic techniques \\ Monitoring endometriosis in a clinical setting}

Definitive diagnosis of endometriosis is notoriously difficult. Laparoscopy is currently the gold standard for diagnosis [167]. Endometriosis manifests in peritoneal congestion, adhesions, and other defects, which are readily observed by laparoscopy. Additionally, if laparoscopic findings are suspicious a biopsy can be obtained. Histological diagnosis of endometriosis, while confirmative, is often difficult [168]. Indeed, the sensitivity and specificity of either laparoscopy or biopsy are not sufficient to justify routine clinical use either for diagnosis or monitoring. Furthermore, both of these techniques are invasive and, therefore, present a major barrier to effective clinical management of endometriosis. 
High-resolution transvaginal ultrasonography and, in particular, MR imaging are increasingly used to diagnose the presence and extent of infiltrating lesions [167]. Transvaginal sonography is useful in the diagnosis of ovarian endometriomata and a pelvic sonogram or ultrasound can detect endometriosis cysts of the ovaries. However, none of these methods are effective to detect endometriotic lesions in the pelvis because endometriosis can look similar to other kinds of ovarian cysts on sonogram. Thus, a surgical evaluation is required if the cyst persists throughout 2 menstrual cycles.

For these reasons, development of sensitive and specific non-invasive tests for endometriosis is a priority for investigators [169]. Many DNA-based non-invasive diagnostics methods are used in the clinical practice in obstetrics and gynecology [170]. A noninvasive test would be useful for early detection and staging of endometriosis in symptomatic women who have pelvic pain and/or subfertility with normal ultrasound results. Currently, there are several diagnostic tests including panels of known peripheral blood biomarkers, protein/peptide markers, and miRNAs. However, no reliable blood test for endometriosis exists [171]. Nonetheless, with the maturation of genomic and proteomic technology we are closer than ever to identifying a blood test for rapid and reliable diagnosis of this debilitating disease. So far, studies have focused on glycoproteins, cytokines, adhesion molecules, as well as angiogenic and growth factors, which are all associated with the pathogenesis of endometriosis and the development of endometriotic lesions [171].

Biomarkers such as annexin V, vascular endothelial growth factor (VEGF), CA-125, and soluble intercellular adhesion molecule-1 (sICAM-1/or glycodelin) [Figure 4] in plasma samples have been shown in the multivariate analysis to diagnose endometriosis that was undetectable by ultrasound with a sensitivity of $81 \%$ to $90 \%$ and a specificity of $63 \%$ to $81 \%$ [171]. Specifically, cancer antigen 125 (CA-125) has come into common use as a peripheral biomarker of endometriosis [172]. CA-125 is known to be produced by endometrial and mesothelial cells and enters the circulation in response to inflammation via the endothelial lining of capillaries. Moderate elevation of serum CA125 has been observed in endometriosis, particularly in patients with severe disease [173,174]. However, CA-125 levels in peripheral blood lack diagnostic power as a single biomarker of endometriosis due to low sensitivity [172].

Studies investigating of serum cytokines as biomarkers have demonstrated significant elevation of levels of interleukin-6, monocyte chemotactic protein-1, and interferon-gamma in serum of subjects with endometriosis compared to healthy women. However, the authors suggest that only IL-6 provides a promising serum marker for nonsurgical diagnosis of endometriosis because
IL-6 has higher specificity alone then when adding serum IL-6, MCP-1, and INF-g together. Additionally, IL-6 levels did not change during any phase of the menstrual cycle [175]. A study by Wang et al. demonstrated that the circulating miRNAs miR-199a, miR-122, miR-145*, and miR-542-3p could potentially serve as noninvasive biomarkers for endometriosis [146]. This was the first report that circulating miRNAs serve as biomarkers of endometriosis.

One potential method for analyzing the differences between the stages of endometriosis in order to personalize treatment is to apply gene expression analysis and measure the signaling pathway activation profiles $[176,177]$, which could be considered for further investigation of possible personalized science research projects [178]. It is possible that different subsets of biomarkers may be required for the diagnosis of different stages of endometriosis.

\section{Epigenetics of endometriosis}

The word 'epigenetics' refers to the study of heritable changes in gene expression that occur without changes in the DNA sequence [179], which includes mechanisms such as DNA methylation, histone modification, and transcription factor regulation [180]. Cancer and many other diseases show aberrant epigenetic regulation [181]. There is accumulating evidence to support the etiology of endometriosis as an epigenetic disease [182,183]. However, much remains to be studied in order to fully evaluate the role of epigenetic factors in the development of endometriosis.

DNA methylation is the best understood and currently most extensively studied epigenetic mechanism. The modification, specifically the attachment of a methyl group to the 5-carbon position of cytosine bases, occurs within the $\mathrm{CpG}$ dinucleotides and is mediated by DNMTs [184,185]. DNA methylation plays an important role in cellular processes and regulation of gene expression and DNA methylation at CpG islands is invariantly associated with gene silencing. The methylated CpGs are docking sites for silencer-type transcription factors that contain a methyl CpG-binding domain (MBD) [186]. DNMTs are divided into two main categories: enzymes involved in the maintenance of DNA methylation (DNMT1) and enzymes involved in de novo DNA methylation (DNMT3A and DNMT3B) [187]. The overexpression of the DNMTs may be a prerequisite for DNA hypermethylation [188]. DNMT1, DNMT3A and DNMT3B are overexpressed in the epithelial component of endometriotic implants. In contrast, only DNMT3A was found to be upregulated in the eutopic endometrium of women with endometriosis [189]. A positive correlation has been noted among these three DNMTs. The upregulated expression of DNMTs in endometriotic tissue 


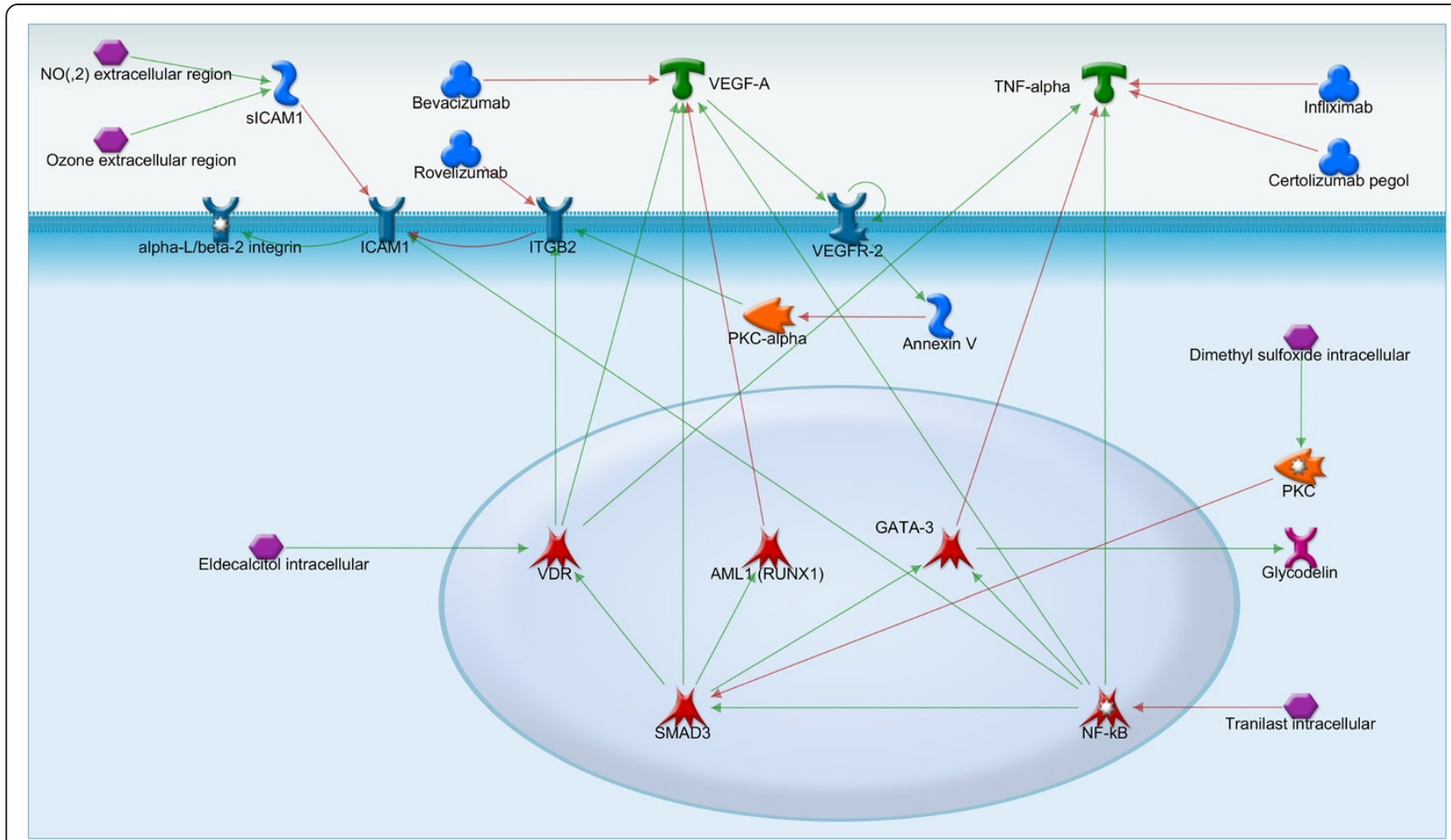

Figure 4 Intracellular regulation of TNF-alpha, VEGF-A, sICAM1 and annexin V. VEGF-A may activate annexin V, a marker of apoptosis, through VEGFR-2. TNF-alpha is regulated by such transcriptional factors as VDR, GATA-3, and NF-kB and is involved in signaling pathways of many growth factors. sICAM1, one of the adhesion molecules involved in the implantation and development of endometriotic lesions, is activated by NF-kB. There are a lot of drugs that have an effect on TNF-alpha, annexin V, VEGF-A and might be potentially used in the treatment of endometriosis.

suggests that hypermethylation may frequently occur in endometriosis. Several factors have been reported to induce DNA methylation, including aging, diet, chronic inflammation, prolonged transcriptional suppression, and environment [190-193]. These aberrations are likely to be responsible for observed phenotypic aberrations at hormonal, biochemical, inflammatory, immunologic, angiogenic, apoptotic, and, ultimately, clinical levels in endometriosis, which are manifested as the excessive local production of estrogen and prostaglandin, inflammation, development of progesterone resistance, altered apoptotic mechanisms, and implantation failure. Because endometriosis is a persistent disease, it is speculated that chronic inflammation, a feature of endometriotic tissue, may induce aberrant DNA methylation [194]. However, the aging cell undergoes a DNA methylation drift. Early studies showed that global DNA methylation decreases during aging in many tissue types [195]. Several specific regions of the genomic DNA become hypermethylated during aging [196]. Interestingly, genes with increased promoter methylation during aging include the E-cadherin gene, which is downregurated and hypermethylated in endometriotic cells $[197,198]$.

There has been a revolution in DNA methylation analysis technology [194]. A number of aberrantly expressed genes have been reported in endometriosis, which could be related to aberrant DNA methylation [199,200]. Particularly, ER $\beta$ up-regulation in endometriotic cells may be related to the hypomethylation of the ER $\beta$-promoter region and decreased PR-B expression in endometriotic tissue could be related with the hypermethylated promoter region of PR-B gene [201,202]. Aromatase is a key molecule for estrogen production and has been demonstrated to be regulated by DNA-methylation in endometriosis [194]. Unmethylated CpG islands within the aromatase gene in endometriotic cells may lead to its up-regulation [194,203]. Downregulation of E-cadherin has been shown in endometriotic cells and may occur due to hypermethylation at the promoter region [198,204]. Steroidogenic factor-1 (SF-1) is a transcriptional factor essential for estrogen biosynthesis and has aberrant expression in endometriotic lesions compared to eutopic endometrium [205-207]. Increased expression of SF-1 in endometriotic cells is related to demethylation of the SF-1 gene promoter that leads to interaction with SF-2, which activates its transcription in endometriotic cells. On other hand, demethylation of the SF-1 gene promoter excludes binding of transcription factor MBD2, which prevents its interaction with transcriptional activators, resulting in silencing of the SF-1 gene [208]. SF-1 expression in endometriosis may enhance aromatase expression 
leading to local estrogen production [194]. In women with endometriosis, HOXA10 expression is significantly decreased in the eutopic endometrium during the secretory phase, indicating functional defects in uterine receptivity $[157,209]$. The promoter region of HOXA10 gene was found to be hypermethylated in the eutopic endometrium of women with endometriosis and may be a cause of HOXA10 downregulation $[157,210]$. Using the epigenetic concept as the lens, new diagnostic markers or therapies may be developed to overcome serious problems in patients with endometriosis.

\section{Current treatment methods Hormone therapies}

Hormone therapy for endometriosis is frequently effective at reducing or even eliminating the pain of the disease [211]. The primary mechanism of action of hormone therapy is to inhibit estrogen production [211].

The success of various hormonal therapies depends on the localization and type of the endometriotic lesions. Superficial peritoneal and ovarian implants seem to respond better to hormone therapy than deep ovarian or peritoneal lesions or lesions within organs [211]. Moreover, hormone treatment has no effect on adhesion of endometriotic cells and cannot improve fertility. Nonetheless, a number of hormonal agents remain the mainstay of endometriosis therapy.

\section{Prostaglandin synthetase inhibitors (PGSIs)}

PGSIs are a heterogeneous group of non-steroidal inflammatory agents that inhibit the production of prostaglandins [212]. PGSIs are effective in the early stages of endometriosis, but lose efficacy when symptoms become more severe [212]. Nevertheless a lot of side effects such as skin reactions, bronchospasm, and serious blood dyscrasias have been reported for several of these drugs [213].

\section{Levonorgestrel intrauterine system}

The levonorgestrel intrauterine system (LNG-IUS) is a long-acting contraceptive method, which acts through a steady low level of LNG in the peripheral circulation. The LNG-IUS appears to have a direct effect on the growth of endometriotic deposits through peritoneal fluid [214]. The suppression of menstruation, or marked reduction of flow, may also be beneficial in reducing the amount of retrograde menstruation. One of the side effects of the LNGIUS is thinning of the endometrium, which causes a decrease in menstrual blood loss and a high incidence of amenorrhea. Thereby the LNG-IUS is used as a treatment for dysmenorrhea, menorrhagia and endometriosis [215].

A study comparing LNG-IUS with expectant management demonstrated significantly lower pain scores in the LNG-IUS participants at 12 months [216]. In the second trial LNG-IUS was compared with a GnRH analogue and found to be equally effective in reducing pain scores after 6 months [217].

\section{Oral contraceptives (OCPs)}

OCPs contain both estrogen and progesterone and regulate the monthly development of the endometrial lining. Use of OCPs has been suggested to reduce or eliminate the pain associated with endometriosis, making them an attractive long-term treatment option [12]. The most common side effects of OCP treatment are acne, weight gain and irregular withdrawal bleeding [218].

\section{Gonadotropin-releasing hormone (GnRH) agonists}

$\mathrm{GnRH}$ analogues are synthetic hormones that cause an artificial menopause via inhibition of luteinizing hormone (LH) and follicle stimulating hormone (FSH), which in turn decreases estrogen levels preventing menstruation. They can be administered as a nasal spray, by injection, or as an implant [211]. GnRH agonist treatment can force endometriosis into long term remission $[219,220]$. However, this is at the expense of infertility and other side-effects reminiscent of menopause such as hot flashes, vaginal dryness, and bone loss [211,221]. These side-effects can be minimized by co-administration of a low-dose estrogen or progestin hormone replacement therapy (HRT). Infertility resolves shortly after discontinuation of the medication.

\section{Progestogens}

Progestogens are synthetic progesterone analogues that prevent ovulation. Both injectable progestogens such as medroxyprogesterone (Depo-Provera) and intrauterine systems (Mirena) have been successfully used to treat endometriosis [211]. The most common side effects are irregular menstrual periods, stopping of menstrual bleeding, weight gain.

\section{Antiprogestogens}

Also known as synthetic testosterone derivatives, antiprogestogens are synthetic hormones that bring on an artificial menopause by decreasing the production of estrogen and progesterone. Antiprogestogens suppress the growth of the endometrium and the symptoms of endometriosis by blocking the production of ovarianstimulating hormones ( $\mathrm{LH}$ and FSH) [211]. Side effects of antiprogestogens comprise acne, weight gain, mood changes and the development of masculine features such as hair growth and a deepening voice.

\section{Bioinformatics analysis \\ Genome wide association studies (GWAS) - genetic biomarkers}

There are four GWAS for endometriosis susceptibility currently listed in the National Human Genome Institute's 
catalog [222-225]. Three of which were conducted in a population primarily of Japanese ancestry [222,224,225]. The GWAS listed in the catalog include only those publications attempting to query at least 100,000 single nucleotide polymorphisms (SNPs) in the initial stage. There are also 20 GWAS that are not listed in the catalog. However, the clinical utility of defining SNPs in endometriosis remains questionable. It is likely that SNP-based testing for endometriosis will convey insufficient diagnostic power and will have be combined with protein biomarkers identified from transcriptome analyses.

\section{Transcriptome studies}

We analyzed the available microarray data in order to identify differentially regulated signaling pathways that may be involved in the pathogenesis of endometriosis. Further analysis of these pathways may reveal proteins, peptides, or mRNAs that may be useful as biomarkers of the disease or as potential therapeutic targets.

\section{Signal transducers and activators of transcription (STATs)}

Network analysis revealed that signal transducers and activators of transcription (STAT) proteins formed a central node of regulation for a majority of the pathways. STATs are a family of seven transcription factors that reside in the cytoplasm in the inactivated form. The STATs can be divided into two groups based on function. The first group, STAT2, 4, and 6, are activated by cytokines and are involved in T-cell development in IFN- $\gamma$ signaling [226]. STAT1, 3, and 5 are primarily activated by growth factors and regulate proliferation and apoptosis [226]. A number of growth factors are known to contribute to the increased proliferative potential of cells derived from endometriotic lesions. The effects of EGF, PDGF, FGFR, IL-6, HGF and VEGF are all primarily achieved through STAT activation [Figure 5].

STATs are latent transcription factors that reside in the cytoplasm. They are primarily activated via C-terminal phosphorylation by Janus kinase (JAK), which induces nuclear translocation of STAT via importin $\alpha-5$ and the Ran nuclear import pathway [227]. However, some growth factor receptors, including EGFR, HGFR, and PDGFR, have intrinsic tyrosine kinase activity allowing them to directly phosphorylate and activate STAT [228]. Once in the nucleus, dimerized STATs bind specific regulatory sequences to activate or repress the transcription of target genes [227]. STATs mediate effects through transcriptional activation of target genes that enhance proliferation (CCND1 and c-Myc), angiogenesis (VEGFA, ADM and ANGPTL4), invasion (FGA, FGB, CTSB and

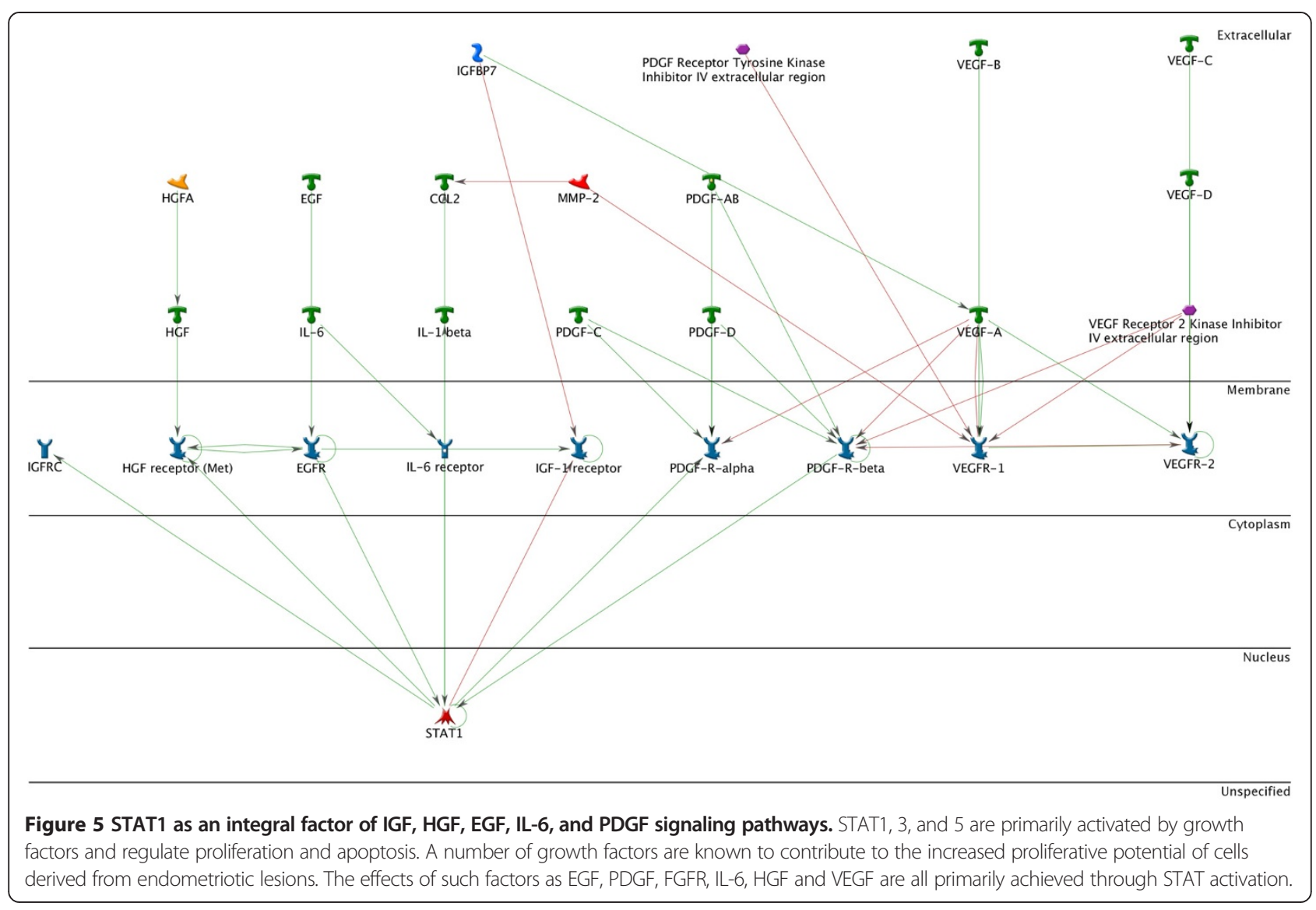


SERPINE2), and suppression of apoptosis (Bcl-xL, Bcl-2, Mcl-1 and Survivin) [229] [Figure 6].

STAT5 regulates the genetic transcription of cyclins and constitutive activation of STAT5 deregulates the cyclin complexes D/CDK4-6, which control progression from the G1 to the S-phase of the cell cycle [230]. Furthermore, the constitutive activation of STAT5 induces antiapoptotic signals including Bcl-xL [231].

Alternatively, no STAT3 mutations inducing constitutive activation have been identified. Rather, dimerized mutant forms called STAT3C, which require no phosphorylation to become active, are able to migrate to the nucleus, guide transcription, and induce cell transformation [232]. As with STAT5, the constitutive activation of STAT3 both induces proliferation and inhibits apoptosis. STAT3 plays an important role in the G1-S cell-cycle transition since it upregulates cyclins D (D1, 2, 3) and A (cdc25A), and downregulates p21 and p27 [233]. STAT3 can also activate proangiogenic factors such as VEGF [234].

Since endometriosis develops through mechanisms that include proliferation, inhibition of apoptosis, migration, and angiogenesis, it is feasible that STATs may play a key role in the pathogenesis of endometriosis as a master regulator of many of these pathways.

\section{SMAD transcription factors}

Other key regulators mediating growth factor pathways are the SMAD transcription factors. The SMAD proteins are the only family of transcription factors known to propagate TGF- $\beta$ signals. However, they also regulate other growth factor pathways, including PDGF, VEGF, and HGF [235].

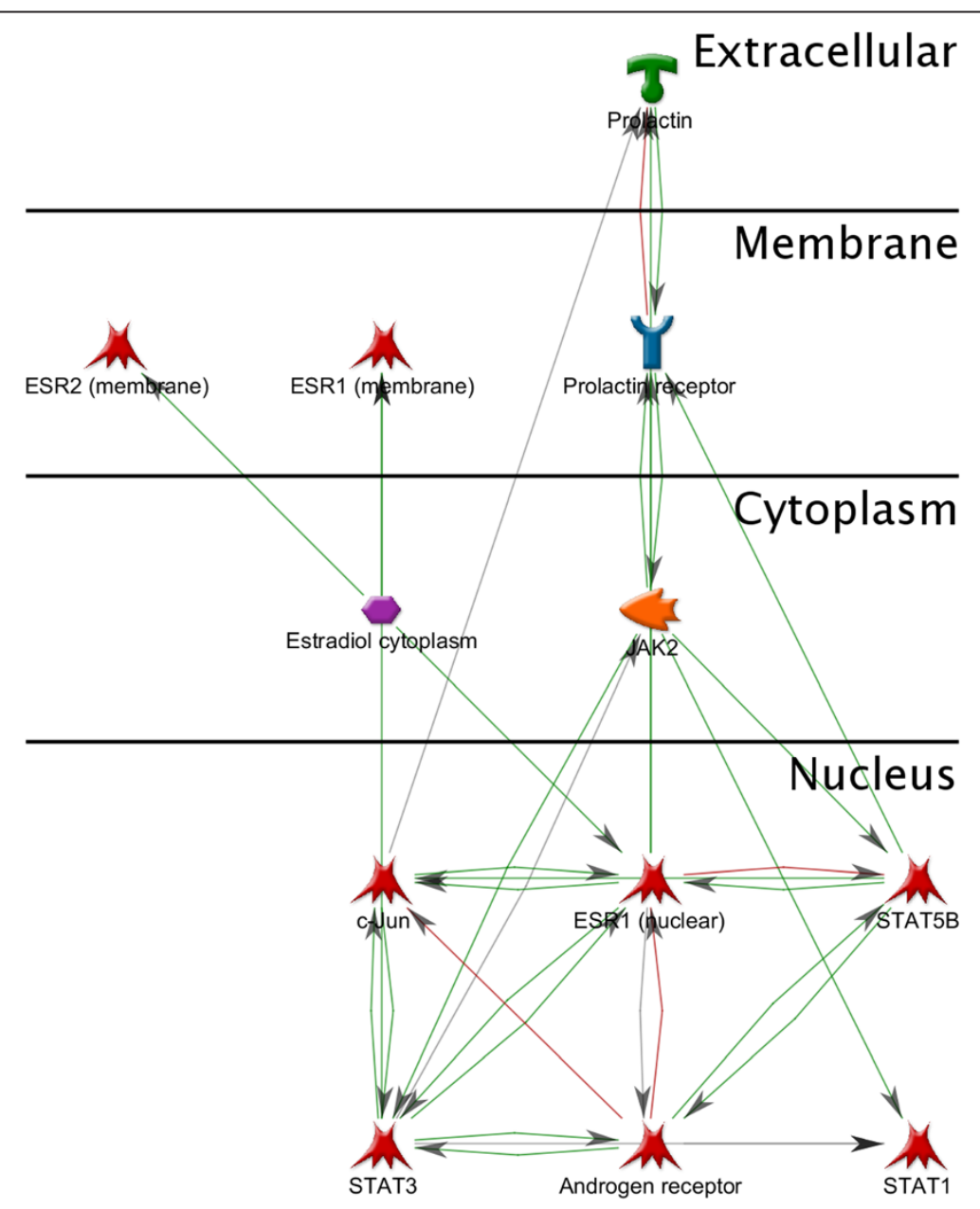

Unspecified

Figure 6 Intracellular interactions of estradiol, androgens and prolactin. Estradiol, androgens and prolactin signaling pathways also pass through the STATs. STAT1 and STAT3 contribute to the implementation of their effects. 
TGF- $\beta$ is a serine-threonine kinase that regulates cell proliferation through the phosphorylation of SMADs, which induces their nuclear translocation [236]. Activated TGF- $\beta$ phosphorylates the R-SMADs (receptor activated), which includes SMAD2 and SMAD3. Phosphorylated R-SMADs bind to SMAD4 and translocate to the nucleus as a complex [236]. SMAD4 is required for the formation of an active transcriptional complex [237].

A diverse array of genes is subsequently regulated by SMAD signaling. Proliferation signals under the transcriptional control of TFG- $\beta$ and SMADs include cyclin-D1, cyclin-dependent kinase 4, p21, p27, p15, and c-myc [238]. TGF- $\beta$ is well known to be a pro-apoptotic protein, regulating expression of Bad and caspase-3 [239]. Additionally, ECM proteins including fibronectin, collagen, and MMPs, are also regulated by SMAD signaling [238,239].

In addition to all of these pathways, which are fairly well understood in relation to TGF- $\beta$ /SMAD signaling, this key regulatory node may also contribute to a compromised immune status, which allows for formation of endometriotic lesions. Firstly, TGF- $\beta$ secretion from increased numbers of macrophages in the peritoneal fluid of women with endometriosis can induce expression of monocyte chemoattractant protein-1 (MCP-1) as well as COX-2 and PGE2. The upregulation of these signals results in a chronic inflammatory response [239]. Furthermore, SMAD-deficient mice have demonstrated defects in T-cell differentiation leading to an imbalance of effector and regulatory lymphocytes. Loss of immune system homeostasis could contribute to the pathogenesis of endometriosis [240].

\section{MEK/ERK}

Perhaps the most crucial signaling node identified in our studies is the mitogen-activated protein kinase (MAPK)/ extracellular signal-regulated kinase (ERK) or MEK pathway. This pathway has been extensively studied over the past few decades and has well defined roles in regulation of signaling for proliferation, apoptosis, adhesion, invasion, angiogenesis, and evasion of immune surveillance [241,242]. ERK controls transcriptional expression of c-myc and c-Fos, which are both involved in cell-cycle progression and cellular proliferation [243]. In the cytoplasm, ERK is responsible for the regulation of the ribosomal S6 kinase (RSK) family proteins, which subsequently regulate cell-cycle progression via expression of

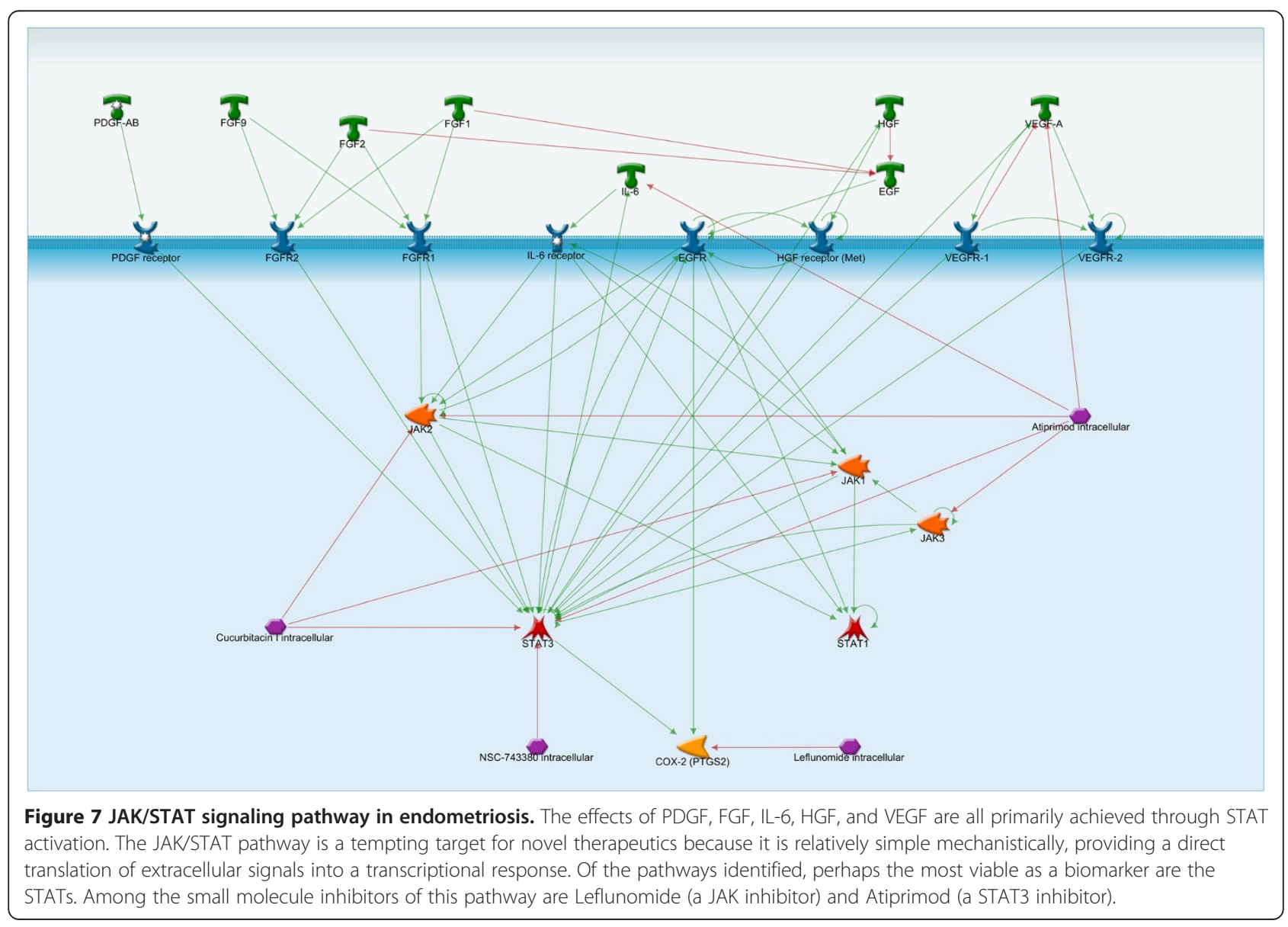


p27, apoptosis via inhibition of Bad, as well a number of other signaling cascades via the transcription factors NF- $k B$ and estrogen receptor- $\alpha$ [243]. ERK also has effects on the ECM via regulation of the actin-binding protein paladin [243]. The contribution of MEK/ERK to cell adhesion, migration, and invasion is partly mediated through its regulation of the down-stream TGF- $\beta /$ SMAD pathway [242]. Lastly, the MEK/ERK pathway has been suggested to contribute to evasion of immune surveillance by promoting the downregulation of cell-surface antigens that would be recognized by T-cells [242].

The MEK/ERK pathway is upstream of many of the other signaling nodes identified in our analysis, which indicates that it may be a master regulator of the majority of the signaling pathways and cascades involved in the pathogenesis of endometriosis and, therefore, highly important as a potential therapeutic target [241].

\section{Prospective biomarkers}

A great deal of research has recently been devoted to the identification of biomarkers for diagnosis of endometriosis. While some putative candidates have been identified, they lack sufficient sensitivity and specificity to be clinically useful. The results of our bioinformatics analysis align with those previous findings in that the pathways identified are ubiquitous key regulatory pathways. As such, they are involved in numerous signaling cascades controlling cell proliferation, apoptosis, invasion, and have implications in a variety of disease processes.

We used Metacore software for bioinformatics analysis of the main signaling pathways involved in pathogenesis of endometriosis. Metacore software provides an opportunity to model disease pathways and targets allow assessment of biomarkers. Of the pathways identified, perhaps the most viable as a biomarker are the STATs. A meta-analysis of biomarker studies identified numerous cytokines as being potentially diagnostic for endometriosis [172]. Many of these cytokines transduce signals through STATs. Therefore, STATs may serve as a convergent, and thereby more sensitive, readout of cytokine status.

\section{Prospective treatment methods}

In addition to their potential role as biomarkers of endometriosis the signaling molecules and pathways

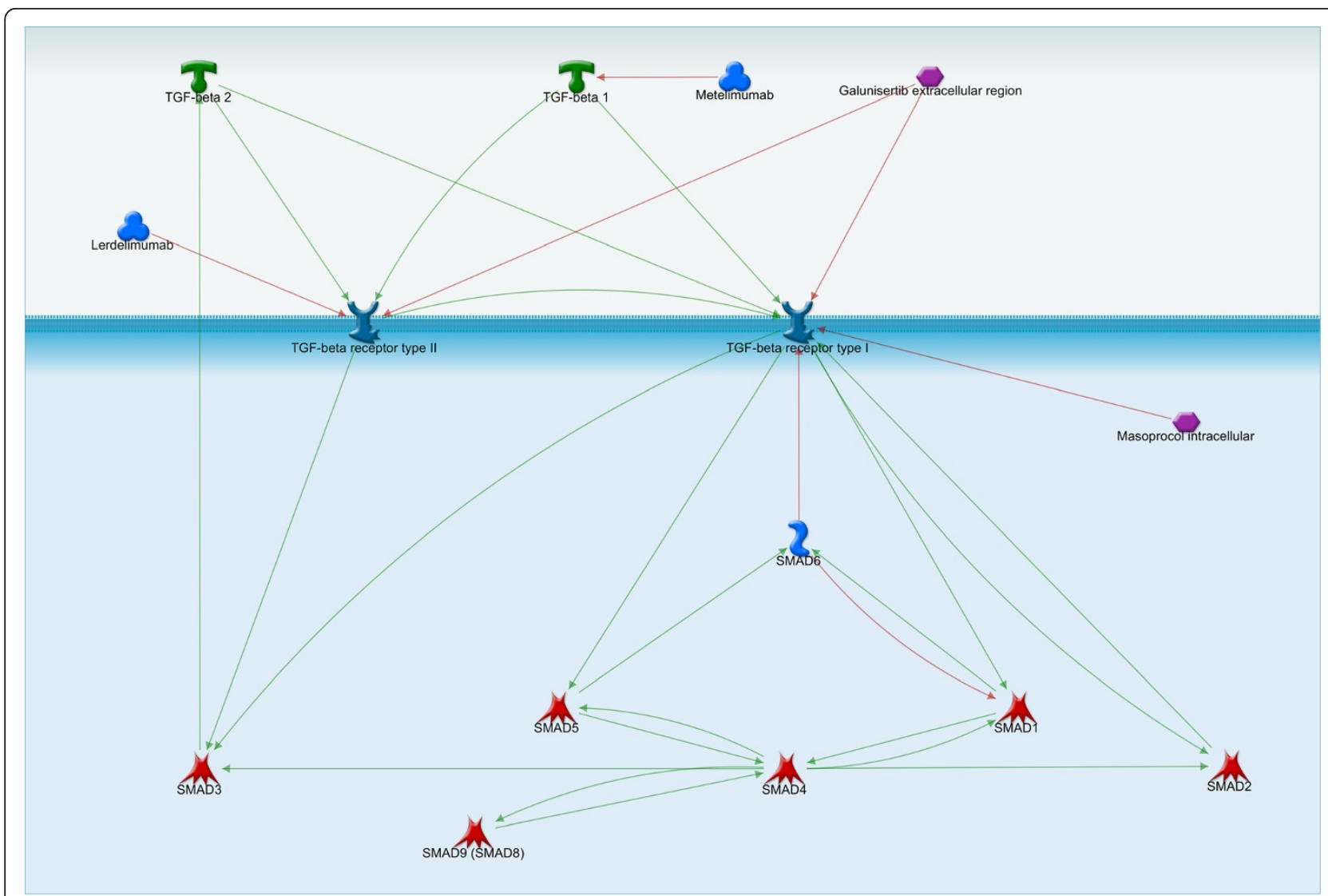

Figure 8 TGF- $\beta$ /SMAD signaling pathway. The SMAD proteins are the only family of transcription factors known to propagate TGF- $\beta$ signals. Lerdelimumab (a recombinant human IgG4 targeting TGF- $\beta 2$ ) and Metelimumab (a human monoclonal lgG4 against TGF- $\beta 1$ ) can inhibit TGF- $\beta$ signaling. 
identified by our analysis may also provide insights into new therapies.

JAK/STAT The JAK/STAT pathway is a tempting target for novel therapeutics because it is relatively simple mechanistically, providing a direct translation of extracellular signal into a transcriptional response. There are several small molecule drug candidates that have been shown to regulate the JAK/STAT pathway and several are already on the market while others are still in clinical trials [244].

Leflunomide is a JAK inhibitor that is used to treat rheumatoid arthritis (RA) and fibrosis. In model cell lines, leflunomide primarily inhibits cell migration through inhibitory effects on ECM proteins such as collagen [244]. Though it has also been shown to block cell proliferation through various JAK mediated pathways [Figure 7].

Atiprimod is a STAT3 inhibitor currently in clinical trials. In multiple myeloma cells lines it has been shown to induce apoptosis via cleavage of caspase- 3 and downregulation of Bcl-2 [244]. Furthermore, it has been shown to have anti-inflammatory effects in animal models of RA via inhibition of IL-6 production [244].

TGF- $\boldsymbol{\beta}$ /SMAD Novel therapeutics aimed at inhibition of the TGF- $\beta /$ SMAD pathway have taken three forms:
(1) translational inhibition using antisense oligonucleotides, (2) inhibition of the ligand/receptor interaction using monoclonal antibodies, and (3) small molecule inhibitors of the signaling cascade [245]. Several antisense oligonucleotide therapies are in clinical trials and have demonstrated great efficacy in cell models. However, thus far, clinical results have been disappointing [245]. Alternatively, several monoclonal antibodies have shown significant promise.

Lerdelimumab is a recombinant human IgG4 targeting TGF- $\beta 2$, which is currently in clinical trials for treatment of post-surgical fibrosis [245]. Metelimumab is a human monoclonal IgG4 against TGF- $\beta 1$ currently being developed to treat scleroderma [245]. GC-1008 targets all TGF- $\beta$ isoforms and is in clinical trials for treatment of melanoma and renal cell carcinoma [245]. Each of these antibodies showed enough promise in early stage clinical trials to warrant advancement to stage II/III clinical trials, which are still currently underway [Figure 8].

Several small molecule inhibitors are also being developed. SD-093 and LY-580276, which are primarily inhibitors of SMAD2/3 activity, have been shown to inhibit cell migration and invasion in cell culture models and are proceeding to clinical trials [245].

The TGF- $\beta /$ SMAD signaling pathway is much more complex than that of JAK/STAT and is known to have

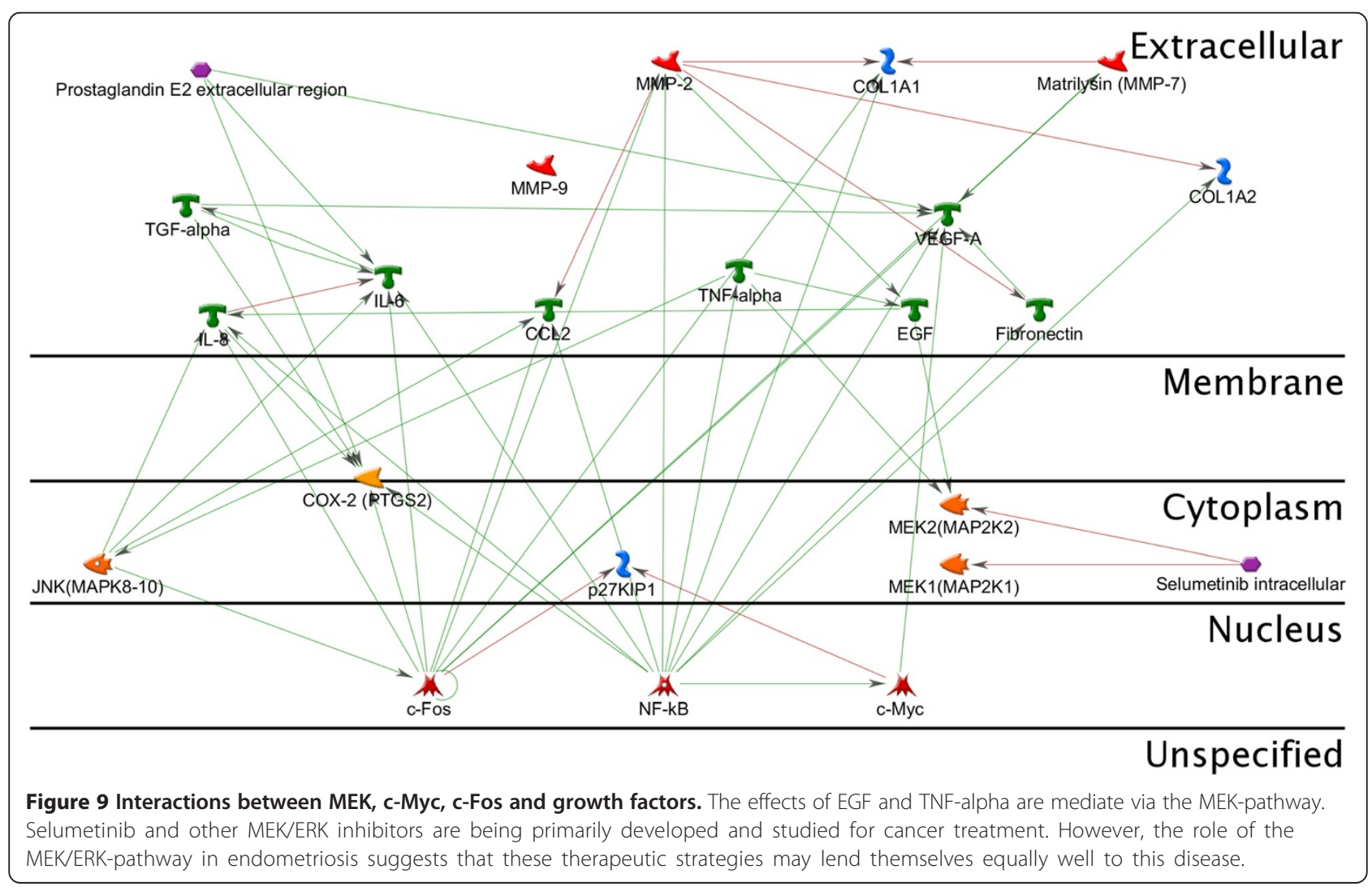


dual roles in regulation of cell proliferation. The balance of pro-proliferative and anti-proliferative effects must be maintained in an effective therapy targeting this pathway. Therefore, therapeutic development will be complex.

MEK/ERK Perhaps the most well studied pathway, MEK/ERK signaling has several distinct advantages as a therapeutic target. Firstly, most MEK inhibitors that have been developed are very specific and do not inhibit many different protein kinases [241]. Secondly, unlike the TGF- $\beta /$ SMAD pathway, targeting of MEK is highly specific as ERK is the only known effector and the downstream targets are fairly well defined [241]. Lastly, MEK/ERK signaling represents a convergence of many upstream signaling pathways that could be inhibited with a single therapeutic.

Selumetinib is a small molecular inhibitor of MEK that recently entered phase III clinical trials for treatment of non-small cell lung cancer. Selumetinib has been shown to be effective for inhibition of cell proliferation in several tumor models, but does not affect the growth of normal human cells [241]. It is thought that selumetinib is cytostatic, meaning that it inhibits proliferation via cell cycle arrest but does not induce apoptosis [Figure 9].

Selumetinib and other MEK/ERK inhibitors are being primarily developed and studied for cancer treatment. However, our analysis revealing the critical role of this particular pathway in endometriosis suggests that these therapeutic strategies may lend themselves equally well to this disease.

\section{Conclusions}

Endometriosis is a common and painful condition affecting women of reproductive age and the prevalence is rapidly increasing internationally. However, the global government funding for and the number of research projects focusing on endometriosis have remained at the relatively same level since 2008 and represent a minor fraction of the female genitourinary cancers [178]. There needs to be the increased international effort to understand the etymology of endometriosis, explore preventative methods, and personalize treatment options.

While the underlying pathophysiology is still largely unknown, many advancements have been made in understanding the progression of the disease. In recent years, a great deal of research has focused on noninvasive diagnostic tools, such as biomarkers, as well as identification of potential therapeutic targets. The current diagnostic tools are invasive and current therapies primarily treat the symptoms of endometriosis. Optimally, the advancement of genomic and proteomic data will facilitate the development of non-invasive diagnostic biomarkers as well as therapeutics that target the pathophysiology of the disease and halt, or even reverse, progression. However, the amount of data generated by these types of studies is vast and bioinformatics analysis, such as we present here, will be critical to identification of appropriate targets for further study.

Our network analysis identified the STAT proteins, the SMAD transcription factors, and the MEK/ERK pathways as central regulators for the pathophysiological processes that drive development of endometriosis. Therefore, these proteins and pathways have the potential to yield clinically useful biomarkers and treatments for endometriosis.

\section{Competing interests}

The authors declare that they have no competing interests.

\section{Authors' contributions}

YB has made substantial contributions to acquisition and analysis of data and has participated in the bioinformatics analysis. MB has been involved in drafting the manuscript. TK has participated in the review writing and has revised the draft critically. AM carried out the bioinformatics analysis. AA has revised the draft and has given final approval of the version to be published. All authors read and approved the final manuscript.

\section{Acknowledgements}

We would like to thank professor S.A. Yakovenko of AltraVita and professor S.A. Roumiantsev for many constructive and meaningful comments and suggestions that helped improve the paper and laid the foundation for further research. Authors would like to thank Elena Vyaznikova for general supervision of the research group and the UMA Foundation for its help in preparation of the manuscript.

\section{Author details}

${ }^{1}$ I.M. Sechenov First Moscow State Medical University, Moscow, Russian Federation. ${ }^{2}$ Department of Pathology and Laboratory Medicine, Emory University, Atlanta, GA, USA. ${ }^{3}$ The First Open Institute for Regenerative Medicine for Young Scientists, Moscow, Russian Federation. ${ }^{4}$ The Biogerontology Research Foundation, London, UK. ${ }^{5}$ Federal Research and Clinical Center for Pediatric Hematology, Oncology and Hematology, Moscow, Russian Federation. ${ }^{6}$ Moscow Institute of Physics and Technology, Moscow, Russian Federation.

Received: 16 March 2014 Accepted: 29 May 2014 Published: 13 June 2014

\section{References}

1. Meuleman C, Tomassetti C, Gaspar Da Vitoria Magro M, Van Cleynenbreugel B, D'Hoore A, D'Hooghe T: Laparoscopic treatment of endometriosis. Minerva Ginecol 2013, 65:125-142.

2. Chapron C, Bourret A, Chopin N, Dousset B, Leconte M, Amsellem-Ouazana D, de Ziegler D, Borghese B: Surgery for bladder endometriosis: long-term results and concomitant management of associated posterior deep lesions. Hum Reprod 2010, 25:884-889.

3. Revised american society for reproductive medicine classification of endometriosis: 1996. Fertil Steril 1997, 67:817-821. http://www.ncbi.nlm.nih. gov/pubmed/9130884.

4. Giudice LC, Kao LC: Endometriosis. Lancet 2004, 364:1789-1799.

5. Abbas S, Ihle P, Koster I, Schubert I: Prevalence and incidence of diagnosed endometriosis and risk of endometriosis in patients with endometriosis-related symptoms: findings from a statutory health insurance-based cohort in Germany. Eur J Obstet Gynecol Reprod Biol 2012, 160:79-83.

6. Janssen EB, Rijkers AC, Hoppenbrouwers K, Meuleman C, D'Hooghe TM: Prevalence of endometriosis diagnosed by laparoscopy in adolescents with dysmenorrhea or chronic pelvic pain: a systematic review. Hum Reprod Update 2013, 19(5):570-582.

7. Ballard KD, Seaman HE, de Vries CS, Wright JT: Can symptomatology help in the diagnosis of endometriosis? Findings from a national case-control study-Part 1. BJOG 2008, 115:1382-1391. 
8. Haas D, Chvatal R, Reichert B, Renner $S$, Shebl O, Binder H, Wurm P, Oppelt P: Endometriosis: a premenopausal disease? Age pattern in 42,079 patients with endometriosis. Arch Gynecol Obstet 2012, 286:667-670.

9. McArthur JW, Ulfelder H: The effect of pregnancy upon endometriosis. Obstet Gynecol Surv 1965, 20:709-733.

10. Ueda Y, Enomoto T, Miyatake T, Fujita M, Yamamoto R, Kanagawa T, Shimizu H, Kimura T: A retrospective analysis of ovarian endometriosis during pregnancy. Fertil Steril 2010, 94:78-84.

11. Yuan P, Huang Y, Cheng B, Zhang J, Xin X: Induction of a local pseudo-pregnancy for the treatment of endometriosis. Med Hypotheses 2010, 74:56-58.

12. Davis L, Kennedy SS, Moore J, Prentice A: Modern combined oral contraceptives for pain associated with endometriosis. Cochrane Database Syst Rev 2007, :CD001019.

13. Kistner RW: The use of newer progestins in the treatment of endometriosis. Am J Obstet Gynecol 1958, 75:264-278.

14. Marino JL, Holt VL, Chen C, Davis S: Shift work, hCLOCK T3111C polymorphism, and endometriosis risk. Epidemiology 2008, 19:477-484

15. Bao AM, Liu RY, van Someren EJ, Hofman MA, Cao YX, Zhou JN: Diurnal rhythm of free estradiol during the menstrual cycle. Eur J Endocrinol 2003, 148:227-232.

16. Carandente F, Angeli A, Crosignani P, Dammacco F, De Cecco L, Ferrario VF, Halberg F, Marrama P, Martini L, Massobrio M: Circatrigintan rectal temperature and endocrine rhythms of clinically healthy, menstrually cycling women. Prog Clin Biol Res 1987, 227B:533-548.

17. Chung FF, Yao CC, Wan GH: The associations between menstrual function and life style/working conditions among nurses in Taiwan. J Occup Health 2005, 47:149-156.

18. Kakegawa H, Mitsuo N, Matsumoto H, Satoh T, Akagi M, Tasaka K: Hyaluronidase-inhibitory and anti-allergic activities of the photo-irradiated products of tranilast. Chem Pharm Bull (Tokyo) 1985 33:3738-3744

19. DeVito MJ, Birnbaum LS, Farland WH, Gasiewicz TA: Comparisons of estimated human body burdens of dioxinlike chemicals and TCDD body burdens in experimentally exposed animals. Environ Health Perspect 1995, 103:820-831.

20. Safe SH: Polychlorinated biphenyls (PCBs): environmental impact, biochemical and toxic responses, and implications for risk assessment. Crit Rev Toxicol 1994, 24:87-149.

21. Whitlock JP Jr: The aromatic hydrocarbon receptor, dioxin action, and endocrine homeostasis. Trends Endocrinol Metab 1994, 5:183-188.

22. Rysavy NM, Maaetoft-Udsen K, Turner H: Dioxins: diagnostic and prognostic challenges arising from complex mechanisms. J Appl Toxicol 2013, 33:1-8.

23. Assessment of the health risk of dioxins: re-evaluation of the tolerable daily intake (TDI). Geneva, Switzerland, 25-29 May 1998. Food Addit Contam 2000, 17:223-369. http://www.ncbi.nlm.nih.gov/pubmed/9130884)

24. Lorber M, Patterson D, Huwe J, Kahn H: Evaluation of background exposures of Americans to dioxin-like compounds in the 1990s and the 2000s. Chemosphere 2009, 77:640-651.

25. Cummings AM, Metcalf JL, Birnbaum L: Promotion of endometriosis by 2,3,7,8-tetrachlorodibenzo-p-dioxin in rats and mice: time-dose dependence and species comparison. Toxicol Appl Pharmacol 1996, 138:131-139.

26. Johnson KL, Cummings AM, Birnbaum LS: Promotion of endometriosis in mice by polychlorinated dibenzo-p-dioxins, dibenzofurans, and biphenyls. Environ Health Perspect 1997, 105:750-755.

27. Cummings AM, Hedge JM, Birnbaum LS: Effect of prenatal exposure to TCDD on the promotion of endometriotic lesion growth by TCDD in adult female rats and mice. Toxicol Sci 1999, 52:45-49.

28. Rier SE, Martin DC, Bowman RE, Dmowski WP, Becker JL: Endometriosis in rhesus monkeys (Macaca mulatta) following chronic exposure to 2,3,7,8-tetrachlorodibenzo-p-dioxin. Fundam App/ Toxicol 1993, 21:433-441.

29. Yang JZ, Agarwal SK, Foster WG: Subchronic exposure to 2,3,7,8tetrachlorodibenzo-p-dioxin modulates the pathophysiology of endometriosis in the cynomolgus monkey. Toxicol Sci 2000, 56:374-381.

30. Bruner KL, Matrisian LM, Rodgers WH, Gorstein F, Osteen KG: Suppression of matrix metalloproteinases inhibits establishment of ectopic lesions by human endometrium in nude mice. J Clin Invest 1997, 99:2851-2857.

31. Bruner-Tran KL, Rier SE, Eisenberg E, Osteen KG: The potential role of environmental toxins in the pathophysiology of endometriosis. Gynecol Obstet Invest 1999, 48(Suppl 1):45-56.
32. Heilier JF, Donnez J, Nackers F, Rousseau R, Verougstraete V, Rosenkranz K, Donnez O, Grandjean F, Lison D, Tonglet R: Environmental and host-associated risk factors in endometriosis and deep endometriotic nodules: a matched case-control study. Environ Res 2007, 103:121-129.

33. Mayani A, Barel S, Soback S, Almagor M: Dioxin concentrations in women with endometriosis. Hum Reprod 1997, 12:373-375.

34. Eskenazi B, Mocarelli P, Warner M, Samuels S, Vercellini P, Olive D, Needham L, Patterson D, Brambilla P: Seveso Women's Health Study: a study of the effects of 2,3,7,8-tetrachlorodibenzo-p-dioxin on reproductive health. Chemosphere 2000, 40:1247-1253.

35. Rier SE: The potential role of exposure to environmental toxicants in the pathophysiology of endometriosis. Ann N Y Acad Sci 2002, 955:201-212. discussion 230-202, 396-406

36. Eisenberg $\mathrm{VH}$, Zolti M, Soriano D: Is there an association between autoimmunity and endometriosis? Autoimmun Rev 2012, 11:806-814

37. Bulun SE: Endometriosis. N Engl J Med 2009, 360:268-279.

38. Matarese G, De Placido G, Nikas Y, Alviggi C: Pathogenesis of endometriosis: natural immunity dysfunction or autoimmune disease? Trends Mol Med 2003, 9:223-228.

39. Sundqvist J, Falconer $H$, Seddighzadeh M, Vodolazkaia A, Fassbender A, Kyama C, Bokor A, Stephansson O, Padyukov L, Gemzell-Danielsson K, D'Hooghe TM: Endometriosis and autoimmune disease: association of susceptibility to moderate/severe endometriosis with CCL21 and HLA-DRB1. Fertil Steril 2011, 95:437-440.

40. Sinaii N, Cleary SD, Ballweg ML, Nieman LK, Stratton P: High rates of autoimmune and endocrine disorders, fibromyalgia, chronic fatigue syndrome and atopic diseases among women with endometriosis: a survey analysis. Hum Reprod 2002, 17:2715-2724.

41. Jess T, Frisch M, Jorgensen KT, Pedersen BV, Nielsen NM: Increased risk of inflammatory bowel disease in women with endometriosis: a nationwide Danish cohort study. Gut 2012, 61:1279-1283

42. Mathur SP: Autoimmunity in endometriosis: relevance to infertility. Am J Reprod Immunol 2000, 44:89-95.

43. Inagaki J, Kondo A, Lopez LR, Shoenfeld $Y$, Matsuura E: Pregnancy loss and endometriosis: pathogenic role of anti-laminin-1 autoantibodies. Ann N Y Acad Sci 2005, 1051:174-184

44. Inagaki J, Hao L, Nakatsuka M, Yasuda T, Hiramatsu Y, Shoenfeld Y, Matsuura E: A possible mechanism of autoimmune-mediated infertility in women with endometriosis. Am J Reprod Immunol 2011, 66:90-99.

45. Gajbhiye R, Suryawanshi A, Khan S, Meherji P, Warty N, Raut V, Chehna N, Khole $\mathrm{V}$ : Multiple endometrial antigens are targeted in autoimmune endometriosis. Reprod Biomed Online 2008, 16:817-824.

46. Halme J, Hammond MG, Hulka JF, Raj SG, Talbert LM: Retrograde menstruation in healthy women and in patients with endometriosis. Obstet Gynecol 1984, 64:151-154.

47. Figueira PG, Abrao MS, Krikun G, Taylor HS: Stem cells in endometrium and their role in the pathogenesis of endometriosis. Ann N Y Acad Sci 2011, 1221:10-17.

48. Kao AP, Wang KH, Chang CC, Lee JN, Long CY, Chen HS, Tsai CF, Hsieh TH, Tsai EM: Comparative study of human eutopic and ectopic endometrial mesenchymal stem cells and the development of an in vivo endometriotic invasion model. Fertil Steril 2011, 95:1308-1315. e1301.

49. Gruenwald P: Origin of endometriosis from the mesenchyme of the coelomic walls. Am J Obstet Gynecol 1942, 44:474.

50. Mok-Lin EY, Wolfberg A, Hollinquist H, Laufer MR: Endometriosis in a patient with Mayer-Rokitansky-Kuster-Hauser syndrome and complete uterine agenesis: evidence to support the theory of coelomic metaplasia. J Pediatr Adolesc Gynecol 2010, 23:e35-e37.

51. Kerner H, Gaton E, Czernobilsky B: Unusual ovarian, tubal and pelvic mesothelial inclusions in patients with endometriosis. Histopathology 1981, 5:277-283.

52. Schrodt GR, Alcorn MO, Ibanez J: Endometriosis of the male urinary system: a case report. J Urol 1980, 124:722-723.

53. Drosdzol A, Skrzypulec V: Endometriosis in pediatric and adolescent gynecology. Ginekol Pol 2008, 79:133-136.

54. Hobbs J, Bortnick A: Endometriosis of the lung: an experimental and clinical study. Am J Obstet Gynecol 1940, 40:843.

55. Matsuura K, Ohtake H, Katabuchi H, Okamura H: Coelomic metaplasia theory of endometriosis: evidence from in vivo studies and an in vitro experimental model. Gynecol Obstet Invest 1999, 47(Suppl 1):18-20. discussion 20-12. 
56. Sampson JA: Metastatic or embolic endometriosis, due to the menstrual dissemination of endometrial tissue into the venous circulation. Am J Pathol 1927, 3:93-110. 143.

57. Karak P, Dimick R, Hamrick KM, Schwartzberg M, Saddekni S: Immediate transcatheter embolization of Swan-Ganz catheter-induced pulmonary artery pseudoaneurysm. Chest 1997, 111:1450-1452

58. Merlo M, Brunelli F, Annecchino FP, Crupi G, Terzi A, Ziolkowska L: Arterial switch operation: myocardial ischemia reversed by internal mammary artery graft. Ann Thorac Surg 1996, 62:586-588.

59. Sasson IE, Taylor HS: Stem cells and the pathogenesis of endometriosis. Ann N Y Acad Sci 2008, 1127:106-115.

60. Macer ML, Taylor HS: Endometriosis and infertility: a review of the pathogenesis and treatment of endometriosis-associated infertility. Obstet Gynecol Clin North Am 2012, 39:535-549.

61. Adachi M, Nasu K, Tsuno A, Yuge A, Kawano Y, Narahara H: Attachment to extracellular matrices is enhanced in human endometriotic stromal cells: a possible mechanism underlying the pathogenesis of endometriosis. Eur J Obstet Gynecol Reprod Biol 2011, 155:85-88.

62. Khare VK, Martin DC, Eltorky M: A comparative study of ovarian and pelvic wall-infiltrating endometriosis. J Am Assoc Gynecol LaparosC 1996, 3:235-239.

63. Anaf V, Simon P, Fayt I, Noel J: Smooth muscles are frequent components of endometriotic lesions. Hum Reprod 2000, 15:767-771.

64. Fukunaga M: Smooth muscle metaplasia in ovarian endometriosis. Histopathology 2000, 36:348-352.

65. van Kaam KJ, Schouten JP, Nap AW, Dunselman GA, Groothuis PG: Fibromuscular differentiation in deeply infiltrating endometriosis is a reaction of resident fibroblasts to the presence of ectopic endometrium. Hum Reprod 2008, 23:2692-2700.

66. Mechsner S, Bartley J, Loddenkemper C, Salomon DS, Starzinski-Powitz A Ebert AD: Oxytocin receptor expression in smooth muscle cells of peritoneal endometriotic lesions and ovarian endometriotic cysts. Fertil Steril 2005, 83(Suppl 1):1220-1231.

67. Odagiri K, Konno R, Fujiwara H, Netsu S, Yang C, Suzuki M: Smooth muscle metaplasia and innervation in interstitium of endometriotic lesions related to pain. Fertil Steril 2009, 92:1525-1531.

68. de Arellano ML B, Gericke J, Reichelt U, Okuducu AF, Ebert AD, Chiantera V, Schneider A, Mechsner S: Immunohistochemical characterization of endometriosis-associated smooth muscle cells in human peritoneal endometriotic lesions. Hum Reprod 2011, 26:2721-2730.

69. van Furth $\mathrm{R}$, Cohn ZA: The origin and kinetics of mononuclear phagocytes. J Exp Med 1968, 128:415-435.

70. Murray PJ, Wynn TA: Protective and pathogenic functions of macrophage subsets. Nat Rev Immunol 2011, 11:723-737.

71. Bacci M, Capobianco A, Monno A, Cottone L, Di Puppo F, Camisa B, Mariani M, Brignole C, Ponzoni M, Ferrari S, Panina-Bordignon P, Manfredi A, Rovere-Querini P: Macrophages are alternatively activated in patients with endometriosis and required for growth and vascularization of lesions in a mouse model of disease. Am J Pathol 2009, 175:547-556.

72. Lawson C, Al-Akoum M, Maheux R, Akoum A: Increased expression of interleukin-1 receptor type 1 in active endometriotic lesions. Reproduction 2007, 133:265-274.

73. Lousse JC, Van Langendonckt A, Gonzalez-Ramos R, Defrere S, Renkin E, Donnez J: Increased activation of nuclear factor-kappa B (NF-kappaB) in isolated peritoneal macrophages of patients with endometriosis. Fertil Steril 2008, 90:217-220.

74. Zhang C, Maeda N, Izumiya C, Yamamoto Y, Kusume T, Oguri H, Yamashita C, Nishimori Y, Hayashi K, Luo J, Fukaya T: Killer immunoglobulin-like receptor and human leukocyte antigen expression as immunodiagnostic parameters for pelvic endometriosis. Am J Reprod Immunol 2006, 55:106-114.

75. Lebovic DI, Mueller MD, Taylor RN: Immunobiology of endometriosis. Fertil Steril 2001, 75:1-10.

76. Novembri R, Carrarelli P, Toti $P$, Rocha AL, Borges LE, Reis FM, Piomboni $P$, Florio P, Petraglia F: Urocortin 2 and urocortin 3 in endometriosis: evidence for a possible role in inflammatory response. Mol Hum Reprod 2011, 17:587-593.

77. Jiang QY, Wu RJ: Growth mechanisms of endometriotic cells in implanted places: a review. Gynecol Endocrinol 2012, 28:562-567.

78. Pellegrini C, Gori I, Achtari C, Hornung D, Chardonnens E, Wunder D, Fiche M, Canny GO: The expression of estrogen receptors as well as GREB1, c-MYC, and cyclin D1, estrogen-regulated genes implicated in proliferation, is increased in peritoneal endometriosis. Fertil Steril 2012, 98:1200-1208.

79. Chegini N, Rossi MJ, Masterson BJ: Platelet-derived growth factor (PDGF), epidermal growth factor (EGF), and EGF and PDGF beta-receptors in human endometrial tissue: localization and in vitro action. Endocrinology 1992, 130:2373-2385.

80. Klemmt PA, Carver JG, Koninckx P, McVeigh EJ, Mardon HJ: Endometrial cells from women with endometriosis have increased adhesion and proliferative capacity in response to extracellular matrix components: towards a mechanistic model for endometriosis progression. Hum Reprod 2007, 22:3139-3147

81. Chung HW, Wen Y, Choi EA, Hao L, Moon HS, Yu HK, Polan ML: Pleiotrophin (PTN) and midkine (MK) mRNA expression in eutopic and ectopic endometrium in advanced stage endometriosis. $\mathrm{Mol}$ Hum Reprod 2002, 8:350-355.

82. Olivares C, Bilotas M, Buquet R, Borghi M, Sueldo C, Tesone M, Meresman G: Effects of a selective cyclooxygenase-2 inhibitor on endometrial epithelial cells from patients with endometriosis. Hum Reprod 2008, 23:2701-2708

83. Bergqvist A, Bruse C, Carlberg M, Carlstrom K: Interleukin 1beta, interleukin-6, and tumor necrosis factor-alpha in endometriotic tissue and in endometrium. Fertil Steril 2001, 75:489-495.

84. Yoshida S, Harada T, Mitsunari M, Iwabe T, Sakamoto Y, Tsukihara S, Iba Y, Horie S, Terakawa N: Hepatocyte growth factor/Met system promotes endometrial and endometriotic stromal cell invasion via autocrine and paracrine pathways. J Clin Endocrinol Metab 2004, 89:823-832

85. Matarese G, Alviggi C, Sanna V, Howard JK, Lord GM, Carravetta C, Fontana S, Lechler RI, Bloom SR, De Placido G: Increased leptin levels in serum and peritoneal fluid of patients with pelvic endometriosis. J Clin Endocrinol Metab 2000, 85:2483-2487.

86. Vermot J, Fraulob V, Dolle P, Niederreither K: Expression of enzymes synthesizing (aldehyde dehydrogenase 1 and reinaldehyde dehydrogenase 2) and metabolizaing (Cyp26) retinoic acid in the mouse female reproductive system. Endocrinology 2000, 141:3638-3645.

87. Deng L, Shipley GL, Loose-Mitchell DS, Stancel GM, Broaddus R, Pickar JH, Davies PJ: Coordinate regulation of the production and signaling of retinoic acid by estrogen in the human endometrium. J Clin Endocrinol Metab 2003, 88:2157-2163.

88. Bock KW, Kohle C: Ah receptor: dioxin-mediated toxic responses as hints to deregulated physiologic functions. Biochem Pharmacol 2006, 72:393-404.

89. Hestermann EV, Brown M: Agonist and chemopreventative ligands induce differential transcriptional cofactor recruitment by aryl hydrocarbon receptor. Mol Cell Biol 2003, 23:7920-7925.

90. Safe S, Wormke M, Samudio I: Mechanisms of inhibitory aryl hydrocarbon receptor-estrogen receptor crosstalk in human breast cancer cells. J Mammary Gland Biol Neoplasia 2000, 5:295-306.

91. Yang X, Liu D, Murray TJ, Mitchell GC, Hesterman EV, Karchner SI, Merson RR, Hahn ME, Sherr DH: The aryl hydrocarbon receptor constitutively represses c-myc transcription in human mammary tumor cells. Oncogene 2005, 24:7869-7881.

92. Iba Y, Harada T, Horie S, Deura I, Iwabe T, Terakawa N: Lipopolysaccharide-promoted proliferation of endometriotic stromal cells via induction of tumor necrosis factor alpha and interleukin-8 expression. Fertil Steril 2004, 82(Suppl 3):1036-1042.

93. Garcia-Velasco JA, Mulayim N, Kayisli UA, Arici A: Elevated soluble Fas ligand levels may suggest a role for apoptosis in women with endometriosis. Fertil Steril 2002, 78:855-859.

94. Selam B, Kayisli UA, Garcia-Velasco JA, Akbas GE, Arici A: Regulation of fas ligand expression by IL-8 in human endometrium. J Clin Endocrinol Metab 2002, 87:3921-3927.

95. Watanabe A, Taniguchi F, Izawa M, Suou K, Uegaki T, Takai E, Terakawa N, Harada T: The role of survivin in the resistance of endometriotic stromal cells to drug-induced apoptosis. Hum Reprod 2009, 24:3172-3179.

96. Nishida M, Nasu K, Ueda T, Fukuda J, Takai N, Miyakawa I: Endometriotic cells are resistant to interferon-gamma-induced cell growth inhibition and apoptosis: a possible mechanism involved in the pathogenesis of endometriosis. Mol Hum Reprod 2005, 11:29-34.

97. Pedraza C, Geberhiwot T, Ingerpuu S, Assefa D, Wondimu Z, Kortesmaa J, Tryggvason K, Virtanen I, Patarroyo M: Monocytic cells synthesize, adhere 
to, and migrate on laminin-8 (alpha 4 beta 1 gamma 1). J Immunol 2000, 165:5831-5838.

98. Spuijbroek MD, Dunselman GA, Menheere PP, Evers JL: Early endometriosis invades the extracellular matrix. Fertil Steril 1992, 58:929-933.

99. Lessey BA, Castelbaum AJ, Sawin SW, Buck CA, Schinnar R, Bilker W, Strom BL: Aberrant integrin expression in the endometrium of women with endometriosis. J Clin Endocrinol Metab 1994, 79:643-649.

100. Hinck L, Nathke IS, Papkoff J, Nelson WJ: Dynamics of cadherin/catenin complex formation: novel protein interactions and pathways of complex assembly. J Cell Biol 1994, 125:1327-1340.

101. Shaco-Levy R, Sharabi S, Benharroch D, Piura B, Sion-Vardy N: Matrix metalloproteinases 2 and 9, E-cadherin, and beta-catenin expression in endometriosis, low-grade endometrial carcinoma and non-neoplastic eutopic endometrium. Eur J Obstet Gynecol Reprod Biol 2008, 139:226-232

102. Ris HW: The integration of a comprehensive medical program in a juvenile correctional institution. J Am Med Womens Assoc 1975, 30:367-378

103. Poncelet C, Cornelis F, Tepper M, Sauce E, Magan N, Wolf JP, Ziol M: Expression of $\mathrm{E}$ - and $\mathrm{N}$-cadherin and CD44 in endometrium and hydrosalpinges from infertile women. Fertil Steril 2010, 94:2909-2912.

104. Gaetje R, Kotzian S, Herrmann G, Baumann R, Starzinski-Powitz A: Nonmalignant epithelial cells, potentially invasive in human endometriosis, lack the tumor suppressor molecule E-cadherin. Am J Pathol 1997, 150:461-467.

105. Beliard A, Donnez J, Nisolle M, Foidart JM: Localization of laminin, fibronectin, E-cadherin, and integrins in endometrium and endometriosis. Fertil Steril 1997, 67:266-272.

106. Poncelet C, Leblanc M, Walker-Combrouze F, Soriano D, Feldmann G, Madelenat P, Scoazec JY, Darai E: Expression of cadherins and CD44 isoforms in human endometrium and peritoneal endometriosis. Acta Obstet Gynecol Scand 2002, 81:195-203.

107. Fujimoto J, Ichigo S, Hori M, Tamaya T: Alteration of E-cadherin, alphaand beta-catenin mRNA expression in human uterine endometrium during the menstrual cycle. Gynecol Endocrinol 1996, 10:187-191.

108. Matsuzaki S, Darcha C: Involvement of the Wnt/beta-catenin signaling pathway in the cellular and molecular mechanisms of fibrosis in endometriosis. PLOS One 2013, 8:e76808.

109. Ueda M, Yamashita Y, Takehara M, Terai Y, Kumagai K, Ueki K, Kanda K, Hung YC, Ueki M: Gene expression of adhesion molecules and matrix metalloproteinases in endometriosis. Gynecol Endocrinol 2002, 16:391-402

110. Clevers H, Nusse R: Wnt/beta-catenin signaling and disease. Cell 2012 , 149:1192-1205.

111. Chen GT, Tai CT, Yeh LS, Yang TC, Tsai HD: Identification of the cadherin subtypes present in the human peritoneum and endometriotic lesions: potential role for P-cadherin in the development of endometriosis. $\mathrm{Mol}$ Reprod Dev 2002, 62:289-294.

112. Hull ML, Escareno CR, Godsland JM, Doig JR, Johnson CM, Phillips SC, Smith SK, Tavare S, Print CG, Charnock-Jones DS: Endometrial-peritoneal interactions during endometriotic lesion establishment. Am J Pathol 2008, 173:700-715.

113. Koks CA, Groothuis PG, Dunselman GA, de Goeij AF, Evers JL: Adhesion of menstrual endometrium to extracellular matrix: the possible role of integrin alpha(6)beta(1) and laminin interaction. Mol Hum Reprod 2000, 6:170-177

114. D'Amico F, Skarmoutsou E, Quaderno G, Malaponte G, La Corte C, Scibilia G, D'Agate G, Scollo P, Fraggetta F, Spandidos DA, Mazzarino MC: Expression and localisation of osteopontin and prominin-1 (CD133) in patients with endometriosis. Int J Mol Med 2013, 31:1011-1016.

115. Chang JH, Au HK, Lee WC, Chi CC, Ling TY, Wang LM, Kao SH, Huang YH, Tzeng CR: Expression of the pluripotent transcription factor OCT4 promotes cell migration in endometriosis. Fertil Steril 2013, 99:1332-1339. e1335.

116. Forte A, Schettino MT, Finicelli M, Cipollaro M, Colacurci N, Cobellis L, Galderisi U: Expression pattern of stemness-related genes in human endometrial and endometriotic tissues. Mol Med 2009, 15:392-401.

117. Braundmeier AG, Nowak RA: Cytokines regulate matrix metalloproteinases in human uterine endometrial fibroblast cells through a mechanism that does not involve increases in extracellular matrix metalloproteinase inducer. Am J Reprod Immunol 2006, 56:201-214.

118. Chung HW, Lee JY, Moon HS, Hur SE, Park MH, Wen Y, Polan ML: Matrix metalloproteinase-2, membranous type 1 matrix metalloproteinase, and tissue inhibitor of metalloproteinase-2 expression in ectopic and eutopic endometrium. Fertil Steril 2002, 78:787-795.

119. Sharpe-Timms KL, Keisler LW, Mclntush EW, Keisler DH: Tissue inhibitor of metalloproteinase- 1 concentrations are attenuated in peritoneal fluid and sera of women with endometriosis and restored in sera by gonadotropin-releasing hormone agonist therapy. Fertil Steril 1998 69:1128-1134.

120. Hazzard TM, Molskness TA, Chaffin CL, Stouffer RL: Vascular endothelial growth factor (VEGF) and angiopoietin regulation by gonadotrophin and steroids in macaque granulosa cells during the peri-ovulatory interval. Mol Hum Reprod 1999, 5:1115-1121.

121. Bourlev V, Volkov N, Pavlovitch S, Lets N, Larsson A, Olovsson M: The relationship between microvessel density, proliferative activity and expression of vascular endothelial growth factor-A and its receptors in eutopic endometrium and endometriotic lesions. Reproduction 2006, 132:501-509.

122. Nap AW, Griffioen AW, Dunselman GA, Bouma-Ter Steege JC, Thijssen VL, Evers JL, Groothuis PG: Antiangiogenesis therapy for endometriosis. J Clin Endocrinol Metab 2004, 89:1089-1095.

123. Yancopoulos GD, Davis S, Gale NW, Rudge JS, Wiegand SJ, Holash J: Vascular-specific growth factors and blood vessel formation. Nature 2000 407:242-248.

124. Seppala M, Koistinen $H$, Koistinen $R$, Hautala L, Chiu PC, Yeung WS: Glycodelin in reproductive endocrinology and hormone-related cancer. Eur J Endocrinol 2009, 160:121-133.

125. Julkunen M, Koistinen R, Sjoberg J, Rutanen EM, Wahlstrom T, Seppala M: Secretory endometrium synthesizes placental protein 14. Endocrinology 1986, 118:1782-1786.

126. Telimaa S, Kauppila A, Ronnberg L, Suikkari AM, Seppala M: Elevated serum levels of endometrial secretory protein PP14 in patients with advanced endometriosis. Suppression by treatment with danazol and high-dose medroxyprogesterone acetate. Am J Obstet Gynecol 1989, 161:866-871.

127. Lin YJ, Lai MD, Lei HY, Wing LY: Neutrophils and macrophages promote angiogenesis in the early stage of endometriosis in a mouse model. Endocrinology 2006, 147:1278-1286.

128. Moskalev AA, Aliper AM, Smit-McBride Z, Buzdin A, Zhavoronkov A: Genetics and epigenetics of aging and longevity. Cell Cycle 2014, 13:1063-1077.

129. Khan KN, Masuzaki H, Fujishita A, Kitajima M, Kohno T, Sekine I, Matsuyama T, Ishimaru T: Regulation of hepatocyte growth factor by basal and stimulated macrophages in women with endometriosis. Hum Reprod 2005, 20:49-60.

130. Sacco K, Portelli M, Pollacco J, Schembri-Wismayer P, Calleja-Agius J: The role of prostaglandin E2 in endometriosis. Gynecol Endocrinol 2012, 28:134-138.

131. Urata Y, Osuga Y, Akiyama I, Nagai M, Izumi G, Takamura M, Hasegawa A Harada M, Hirata T, Hirota Y, Yoshino O, Koga K, Kozuma S: Interleukin-4 and prostaglandin E2 synergistically up-regulate 3beta-hydroxysteroid dehydrogenase type 2 in endometrioma stromal cells. J Clin Endocrinol Metab 2013, 98:1583-1590.

132. Herrmann Lavoie C, Fraser D, Therriault MJ, Akoum A: Interleukin-1 stimulates macrophage migration inhibitory factor secretion in ectopic endometrial cells of women with endometriosis. Am J Reprod Immunol 2007, 58:505-513.

133. Itoh H, Sashihara T, Hosono A, Kaminogawa S, Uchida M: Interleukin-12 inhibits development of ectopic endometriotic tissues in peritoneal cavity via activation of NK cells in a murine endometriosis model. Cytotechnology 2011, 63:133-141.

134. Ho HN, Chao KH, Chen HF, Wu MY, Yang YS, Lee TY: Peritoneal natural killer cytotoxicity and CD25+CD3+ lymphocyte subpopulation are decreased in women with stage III-IV endometriosis. Hum Reprod 1995, 10:2671-2675

135. Becker JC, Dummer R, Hartmann AA, Burg G, Schmidt RE: Shedding of ICAM-1 from human melanoma cell lines induced by IFN-gamma and tumor necrosis factor-alpha. Functional consequences on cell-mediated cytotoxicity. J Immunol 1991, 147:4398-4401.

136. Wu MY, Ho HN: The role of cytokines in endometriosis. Am J Reprod Immunol 2003, 49:285-296.

137. Matalliotakis IM, Vassiliadis S, Goumenou AG, Athanassakis I, Koumantakis GE, Neonaki MA, Koumantakis EE: Soluble ICAM-1 levels in the serum of endometriotic patients appear to be independent of medical treatment. J Reprod Immunol 2001, 51:9-19. 
138. Barrier BF, Sharpe-Timms KL: Expression of soluble adhesion molecules in sera of women with stage III and IV endometriosis. I Soc Gynecol Investig 2002, 9:98-101.

139. Hsu CC, Yang BC, Wu MH, Huang KE: Enhanced interleukin-4 expression in patients with endometriosis. Fertil Steril 1997, 67:1059-1064.

140. Hirata T, Osuga Y, Hamasaki K, Yoshino O, Ito M, Hasegawa A, Takemura Y, Hirota Y, Nose E, Morimoto C, Harada M, Koga K, Tajima T, Saito S, Yano T, Taketani Y: Interleukin (IL)-17A stimulates IL-8 secretion, cyclooxygensase-2 expression, and cell proliferation of endometriotic stromal cells. Endocrinology 2008, 149:1260-1267.

141. Zhang L, Khayat A, Cheng H, Graves DT: The pattern of monocyte recruitment in tumors is modulated by MCP-1 expression and influences the rate of tumor growth. Lab Invest 1997, 76:579-590.

142. Kelly RW, Carr GG, Riley SC: The inhibition of synthesis of a beta-chemokine, monocyte chemotactic protein-1 (MCP-1) by progesterone. Biochem Biophys Res Commun 1997, 239:557-561.

143. Baka S, Frangou-Plemenou M, Panagiotopoulou E, Makrakis E, Kaltsakas G, Hassiakos D, Kondi-Pafiti A: The expression of human leukocyte antigens class I and II in women with endometriosis or adenomyosis. Gynecol Endocrinol 2011, 27:419-424.

144. Vernet-Tomas Mdel M, Perez-Ares CT, Verdu N, Molinero JL, Fernandez-Figueras MT, Carreras R: The endometria of patients with endometriosis show higher expression of class I human leukocyte antigen than the endometria of healthy women. Fertil Steril 2006, 85:78-83.

145. Semino C, Semino A, Pietra G, Mingari MC, Barocci S, Venturini PL, Ragni N Melioli G: Role of major histocompatibility complex class I expression and natural killer-like T cells in the genetic control of endometriosis. Fertil Steril 1995, 64:909-916.

146. Wang X, Lin Q, Guo S: Study on polymorphism of human leukocyte antigen I in patients with endometriosis. Zhonghua Fu Chan Ke Za Zhi 2001, 36:150-152.

147. Liu Y, Luo L, Zhao H: Immunohistochemical study of HLA-DR antigen in endometrial tissue of patients with endometriosis. J Huazhong Univ Sci Technolog Med Sci 2002, 22:60-61.

148. Ota H, Igarashi S: Expression of major histocompatibility complex class II antigen in endometriotic tissue in patients with endometriosis and adenomyosis. Fertil Steril 1993, 60:834-838.

149. Barrier BF, Kendall BS, Ryan CE, Sharpe-Timms KL: HLA-G is expressed by the glandular epithelium of peritoneal endometriosis but not in eutopic endometrium. Hum Reprod 2006, 21:864-869.

150. Maeda N, Izumiya C, Taniguchi K, Matsushima S, Fukaya T: Role of NK cells and HLA-G in endometriosis. Front Biosci 2012, 4:1568-1581.

151. Hornung D, Fujii E, Lim KH, Vigne JL, McMaster MT, Taylor RN: Histocompatibility leukocyte antigen-G is not expressed by endometriosis or endometrial tissue. Fertil Steril 2001, 75:814-817.

152. Kitawaki J, Xu B, Ishihara H, Fukui M, Hasegawa G, Nakamura N, Mizuno S, Ohta M, Obayashi H, Honjo H: Association of killer cell immunoglobulin-like receptor genotypes with susceptibility to endometriosis. Am J Reprod Immunol 2007, 58:481-486.

153. Ohlsson Teague EM, Van der Hoek KH, Van der Hoek MB, Perry N, Wagaarachchi P, Robertson SA, Print CG, Hull LM: MicroRNA-regulated pathways associated with endometriosis. Mol Endocrinol 2009, 23:265-275

154. Hawkins SM, Creighton CJ, Han DY, Zariff A, Anderson ML, Gunaratne PH, Matzuk MM: Functional microRNA involved in endometriosis. Mol Endocrinol 2011, 25:821-832.

155. Pan Q, Luo X, Toloubeydokhti T, Chegini N: The expression profile of micro-RNA in endometrium and endometriosis and the influence of ovarian steroids on their expression. Mol Hum Reprod 2007, 13:797-806.

156. Petracco R, Grechukhina O, Popkhadze S, Massasa E, Zhou Y, Taylor HS: MicroRNA 135 regulates HOXA10 expression in endometriosis. J Clin Endocrinol Metab 2011, 96:E1925-E1933.

157. Taylor HS, Bagot C, Kardana A, Olive D, Arici A: HOX gene expression is altered in the endometrium of women with endometriosis. Hum Reprod 1999, 14:1328-1331.

158. Dai L, Gu L, Di W: MiR-199a attenuates endometrial stromal cell invasiveness through suppression of the IKKbeta/NF-kappaB pathway and reduced interleukin-8 expression. Mol Hum Reprod 2012, 18:136-145.

159. Kaluz S, Kaluzova M, Stanbridge EJ: Regulation of gene expression by hypoxia: integration of the HIF-transduced hypoxic signal at the hypoxia-responsive element. Clin Chim Acta 2008, 395:6-13.
160. Tamura M, Sebastian S, Yang S, Gurates B, Fang Z, Bulun SE: Interleukin-1beta elevates cyclooxygenase-2 protein level and enzyme activity via increasing its mRNA stability in human endometrial stromal cells: an effect mediated by extracellularly regulated kinases 1 and 2 . J Clin Endocrinol Metab 2002, 87:3263-3273.

161. Chakrabarty A, Tranguch S, Daikoku T, Jensen K, Furneaux H, Dey SK: MicroRNA regulation of cyclooxygenase-2 during embryo implantation. Proc Natl Acad Sci U S A 2007, 104:15144-15149.

162. Meresman GF, Vighi S, Buquet RA, Contreras-Ortiz O, Tesone M, Rumi LS: Apoptosis and expression of $\mathrm{BCl}-2$ and $\mathrm{Bax}$ in eutopic endometrium from women with endometriosis. Fertil Steril 2000, 74:760-766.

163. Matsuzaki S, Canis M, Pouly JL, Botchorishvili R, Dechelotte PJ, Mage G: Differential expression of genes in eutopic and ectopic endometrium from patients with ovarian endometriosis. Fertil Steril 2006, 86:548-553.

164. Fish JE, Santoro MM, Morton SU, Yu S, Yeh RF, Wythe JD, Ivey KN, Bruneau BG, Stainier DY, Srivastava D: miR-126 regulates angiogenic signaling and vascular integrity. Dev Cell 2008, 15:272-284.

165. Hull ML, Charnock-Jones DS, Chan CL, Bruner-Tran KL, Osteen KG, Tom BD, Fan TP, Smith SK: Antiangiogenic agents are effective inhibitors of endometriosis. J Clin Endocrinol Metab 2003, 88:2889-2899.

166. Schmidt M, Paes K, De Maziere A, Smyczek T, Yang S, Gray A, French D, Kasman I, Klumperman J, Rice DS, Ye W: EGFL7 regulates the collective migration of endothelial cells by restricting their spatial distribution. Development 2007, 134:2913-2923.

167. Brosens I, Puttemans P, Campo R, Gordts S, Kinkel K: Diagnosis of endometriosis: pelvic endoscopy and imaging techniques. Best Pract Res Clin Obstet Gynaecol 2004, 18:285-303.

168. Dmowski WP: Pitfalls in clinical, laparoscopic and histologic diagnosis of endometriosis. Acta Obstet Gynecol Scand Suppl 1984, 123:61-66.

169. Elgafor El Sharkwy IA: Combination of non-invasive and semi-invasive tests for diagnosis of minimal to mild endometriosis. Arch Gynecol Obstet 2013, 288:793-797.

170. Nepomnyashchaya YN, Artemov AV, Roumiantsev SA, Roumyantsev AG, Zhavoronkov A: Non-invasive prenatal diagnostics of aneuploidy using next-generation DNA sequencing technologies, and clinical considerations. Clin Chem Lab Med 2013, 51:1141-1154.

171. Fassbender A, Vodolazkaia A, Saunders P, Lebovic D, Waelkens E, De Moor B, D'Hooghe T: Biomarkers of endometriosis. Fertil Steril 2013, 99:1135-1145.

172. May KE, Conduit-Hulbert SA, Villar J, Kirtley S, Kennedy SH, Becker CM: Peripheral biomarkers of endometriosis: a systematic review. Hum Reprod Update 2010, 16:651-674.

173. Barbieri RL, Niloff JM, Bast RC Jr, Scaetzl E, Kistner RW, Knapp RC: Elevated serum concentrations of CA-125 in patients with advanced endometriosis. Fertil Steril 1986, 45:630-634.

174. Pittaway DE, Douglas JW: Serum CA-125 in women with endometriosis and chronic pelvic pain. Fertil Steril 1989, 51:68-70.

175. Othman Eel D, Hornung D, Salem HT, Khalifa EA, El-Metwally TH, Al-Hendy A: Serum cytokines as biomarkers for nonsurgical prediction of endometriosis. Eur J Obstet Gynecol Reprod Biol 2008, 137:240-246.

176. Buzdin AA, Zhavoronkov AA, Korzinkin MB, Venkova LS, Zenin AA, Smirnov PY, Borisov NM: Oncofinder, a new method for the analysis of intracellular signaling pathway activation using transcriptomic data. Front Genet 2014, 5:55.

177. Zhavoronkov A, Buzdin AA, Garazha AV, Borisov NM, Moskalev AA: Signaling pathway cloud regulation for in silico screening and ranking of the potential geroprotective drugs. Front Genet 2014, 5:49.

178. Zhavoronkov A, Cantor CR: From personalized medicine to personalized science: uniting science and medicine for patient-driven, goal-oriented research. Rejuvenation Res 2013, 16:414-418.

179. Berger SL, Kouzarides T, Shiekhattar R, Shilatifard A: An operational definition of epigenetics. Genes Dev 2009, 23:781-783.

180. Holliday R: Epigenetics: an overview. Dev Genet 1994, 15:453-457.

181. Esteller M: Cancer epigenomics: DNA methylomes and histone-modification maps. Nat Rev Genet 2007, 8:286-298.

182. Nasu K, Kawano Y, Tsukamoto Y, Takano M, Takai N, Li H, Furukawa Y, Abe W, Moriyama M, Narahara H: Aberrant DNA methylation status of endometriosis: epigenetics as the pathogenesis, biomarker and therapeutic target. J Obstet Gynaecol Res 2011, 37:683-695.

183. Guo SW: Epigenetics of endometriosis. Mol Hum Reprod 2009, 15:587-607 
184. Jaenisch R, Bird A: Epigenetic regulation of gene expression: how the genome integrates intrinsic and environmental signals. Nat Genet 2003 33(Suppl):245-254

185. Ehrlich M: Expression of various genes is controlled by DNA methylation during mammalian development. J Cell Biochem 2003, 88:899-910.

186. Hendrich $\mathrm{B}$, Tweedie S: The methyl-CpG binding domain and the evolving role of DNA methylation in animals. Trends Genet 2003, 19:269-277.

187. Ting AH, Jair KW, Suzuki H, Yen RW, Baylin SB, Schuebel KE: Mammalian DNA methyltransferase 1: inspiration for new directions. Cell Cycle 2004, 3:1024-1026.

188. Robertson KD: DNA methylation and human disease. Nat Rev Genet 2005, 6:597-610.

189. Wu Y, Strawn E, Basir Z, Halverson G, Guo SW: Aberrant expression of deoxyribonucleic acid methyltransferases DNMT1, DNMT3A, and DNMT3B in women with endometriosis. Fertil Steril 2007, 87:24-32.

190. Richardson BC: Role of DNA methylation in the regulation of cell function: autoimmunity, aging and cancer. J Nutr 2002, 132:2401S-2405S.

191. Jacob RA, Gretz DM, Taylor PC, James SJ, Pogribny IP, Miller BJ, Henning SM, Swendseid ME: Moderate folate depletion increases plasma homocysteine and decreases lymphocyte DNA methylation in postmenopausal women. J Nutr 1998, 128:1204-1212.

192. Hsieh CJ, Klump B, Holzmann K, Borchard F, Gregor M, Porschen R: Hypermethylation of the p16INK4a promoter in colectomy specimens of patients with long-standing and extensive ulcerative colitis. Cancer Res $1998,58: 3942-3945$

193. Stirzaker C, Song JZ, Davidson B, Clark SJ: Transcriptional gene silencing promotes DNA hypermethylation through a sequential change in chromatin modifications in cancer cells. Cancer Res 2004 64:3871-3877

194. Izawa M, Taniguchi F, Terakawa N, Harada T: Epigenetic aberration of gene expression in endometriosis. Front Biosci (Elite Ed) 2013, 5:900-910.

195. Wilson $\mathrm{VL}$, Jones PA: DNA methylation decreases in aging but not in immortal cells. Science 1983, 220:1055-1057.

196. Issa JP: Age-related epigenetic changes and the immune system. Clin Immunol 2003, 109:103-108.

197. Bornman DM, Mathew S, Alsruhe J, Herman JG, Gabrielson E: Methylation of the E-cadherin gene in bladder neoplasia and in normal urothelial epithelium from elderly individuals. Am J Pathol 2001, 159:831-835.

198. Starzinski-Powitz A, Gaetje R, Zeitvogel A, Kotzian S, Handrow-Metzmacher H, Herrmann G, Fanning E, Baumann R: Tracing cellular and molecular mechanisms involved in endometriosis. Hum Reprod Update 1998, 4:724-729.

199. Nabeshima T, Hiramatsu M, Furukawa H, Kameyama T: Effects of acute and chronic administrations of phencyclidine on the levels of serotonin and 5-hydroxyindoleacetic acid in discrete brain areas of mouse. Life Sci 1985 , 36:939-946.

200. Matsuzaki S, Canis M, Vaurs-Barriere C, Pouly JL, Boespflug-Tanguy O, Penault-Llorca F, Dechelotte P, Dastugue B, Okamura K, Mage G: DNA microarray analysis of gene expression profiles in deep endometriosis using laser capture microdissection. Mol Hum Reprod 2004, 10:719-728.

201. Xue Q, Lin Z, Cheng YH, Huang CC, Marsh E, Yin P, Milad MP, Confino E, Reierstad S, Innes J, Bulun SE: Promoter methylation regulates estrogen receptor 2 in human endometrium and endometriosis. Biol Reprod 2007, 77:681-687

202. Wu Y, Strawn E, Basir Z, Halverson G, Guo SW: Promoter hypermethylation of progesterone receptor isoform $B(P R-B)$ in endometriosis. Epigenetics 2006, 1:106-111.

203. Izawa M, Taniguchi F, Uegaki T, Takai E, Iwabe T, Terakawa N, Harada T: Demethylation of a nonpromoter cytosine-phosphate-guanine island in the aromatase gene may cause the aberrant up-regulation in endometriotic tissues. Fertil Steril 2011, 95:33-39.

204. Wu Y, Starzinski-Powitz A, Guo SW: Trichostatin A, a histone deacetylase inhibitor, attenuates invasiveness and reactivates $\mathrm{E}$-cadherin expression in immortalized endometriotic cells. Reprod Sci 2007, 14:374-382.

205. Rice DA, Mouw AR, Bogerd AM, Parker KL: A shared promoter element regulates the expression of three steroidogenic enzymes. Mol Endocrinol 1991, 5:1552-1561.

206. Xue Q, Lin Z, Yin P, Milad MP, Cheng YH, Confino E, Reierstad S, Bulun SE: Transcriptional activation of steroidogenic factor- 1 by hypomethylation of the $5^{\prime}$ CpG island in endometriosis. J Clin Endocrinol Metab 2007, 92:3261-3267.
207. Zeitoun K, Takayama K, Michael MD, Bulun SE: Stimulation of aromatase P450 promoter (II) activity in endometriosis and its inhibition in endometrium are regulated by competitive binding of steroidogenic factor-1 and chicken ovalbumin upstream promoter transcription factor to the same cis-acting element. Mol Endocrinol 1999, 13:239-253.

208. Utsunomiya $H$, Cheng $Y H$, Lin Z, Reierstad S, Yin P, Attar E, Xue Q, Imir G, Thung S, Trukhacheva E, Suzuki T, Sasano H, Kim JJ, Yaegashi N, Bulun SE: Upstream stimulatory factor-2 regulates steroidogenic factor-1 expression in endometriosis. Mol Endocrinol 2008, 22:904-914.

209. Gui Y, Zhang J, Yuan L, Lessey BA: Regulation of HOXA-10 and its expression in normal and abnormal endometrium. Mol Hum Reprod 1999, 5:866-873.

210. Wu Y, Halverson G, Basir Z, Strawn E, Yan P, Guo SW: Aberrant methylation at HOXA10 may be responsible for its aberrant expression in the endometrium of patients with endometriosis. Am J Obstet Gynecol 2005, 193:371-380.

211. Streuli I, de Ziegler D, Santulli P, Marcellin L, Borghese B, Batteux F, Chapron C: An update on the pharmacological management of endometriosis. Expert Opin Pharmacother 2013, 14:291-305.

212. Kauppila A, Puolakka J, Ylikorkala O: Prostaglandin biosynthesis inhibitors and endometriosis. Prostaglandins 1979, 18:655-661.

213. Andersson KE: Side-effects of prostaglandin synthetase inhibitors. Acta Obstet Gynecol Scand Suppl 1979, 87:101-104.

214. Abou-Setta AM, Houston B, Al-Inany HG, Farquhar C: Levonorgestrel-releasing intrauterine device (LNG-IUD) for symptomatic endometriosis following surgery. Cochrane Database Syst Rev 2013, 1, CD005072.

215. Lethaby AE1, Cooke I, Rees M: Progesterone or progestogen-releasing intrauterine systems for heavy menstrual bleeding. Cochrane Database Syst Rev 2005, :CD002126.

216. Vercellini P, Frontino G, De Giorgi O, Aimi G, Zaina B, Crosignani PG: Comparison of a levonorgestrel-releasing intrauterine device versus expectant management after conservative surgery for symptomatic endometriosis: a pilot study. Fertil Steril 2003, 80:305-309.

217. Petta CA, Ferriani RA, Abrao MS, Hassan D, Rosa ESJC, Podgaec S, Bahamondes $L$ : Randomized clinical trial of a levonorgestrel-releasing intrauterine system and a depot $\mathrm{GnRH}$ analogue for the treatment of chronic pelvic pain in women with endometriosis. Hum Reprod 2005, 20:1993-1998.

218. Bahamondes L, Bahamondes MV: New and emerging contraceptives: a state-of-the-art review. Int J Womens Health 2014, 6:221-234.

219. Nirgianakis K, Bersinger NA, McKinnon B, Kostov P, Imboden S, Mueller MD: Regression of the inflammatory microenvironment of the peritoneal cavity in women with endometriosis by GnRHa treatment. Eur J Obstet Gynecol Reprod Biol 2013, 170(2):550-554.

220. Taniguchi F, Higaki H, Azuma Y, Deura I, Iwabe T, Harada T, Terakawa N: Gonadotropin-releasing hormone analogues reduce the proliferation of endometrial stromal cells but not endometriotic cells. Gynecol Obstet Invest 2013, 75:9-15.

221. Rodriguez-Purata J, Coroleu B, Tur R, Carrasco B, Rodriguez I, Barri PN: Endometriosis and IVF: are agonists really better? Analysis of 1180 cycles with the propensity score matching. Gynecol Endocrinol 2013, 29:859-862.

222. Nyholt DR, Low SK, Anderson CA, Painter JN, Uno S, Morris AP, MacGregor S, Gordon SD, Henders AK, Martin NG, Attia J, Holliday EG, McEvoy M, Scott RJ, Kennedy SH, Treloar SA, Missmer SA, Adachi S, Tanaka K, Nakamura Y, Zondervan KT, Zembutsu H, Montgomery GW: Genome-wide association meta-analysis identifies new endometriosis risk loci. Nat Genet 2012, 44:1355-1359.

223. Painter JN, Anderson CA, Nyholt DR, Macgregor S, Lin J, Lee SH, Lambert A, Zhao ZZ, Roseman F, Guo Q, Gordon SD, Wallace L, Henders AK, Visscher PM, Kraft P, Martin NG, Morris AP, Treloar SA, Kennedy SH, Missmer SA, Montgomery GW, Zondervan KT: Genome-wide association study identifies a locus at 7p15.2 associated with endometriosis. Nat Genet 2011, 43:51-54

224. Adachi S, Tajima A, Quan J, Haino K, Yoshihara K, Masuzaki H, Katabuchi H, Ikuma K, Suginami H, Nishida N, Kuwano R, Okazaki Y, Kawamura Y, Sasaki T, Tokunaga K, Inoue I, Tanaka K: Meta-analysis of genome-wide association scans for genetic susceptibility to endometriosis in Japanese population. J Hum Genet 2010, 55:816-821.

225. Uno S, Zembutsu H, Hirasawa A, Takahashi A, Kubo M, Akahane T, Aoki D, Kamatani N, Hirata K, Nakamura Y: A genome-wide association study identifies genetic variants in the CDKN2BAS locus associated with endometriosis in Japanese. Nat Genet 2010, 42:707-710. 
226. Calo V, Migliavacca M, Bazan V, Macaluso M, Buscemi M, Gebbia N, Russo A: STAT proteins: from normal control of cellular events to tumorigenesis. J Cell Physiol 2003, 197:157-168.

227. Liongue C, Ward AC: Evolution of the JAK-STAT pathway. JAKSTAT 2013, 2:e22756.

228. Timofeeva OA, Tarasova NI: Alternative ways of modulating JAK-STAT pathway: Looking beyond phosphorylation. JAKSTAT 2012, 1:274-284.

229. Turkson J, Jove R: STAT proteins: novel molecular targets for cancer drug discovery. Oncogene 2000, 19:6613-6626.

230. Bowman T, Garcia R, Turkson J, Jove R: STATs in oncogenesis. Oncogene 2000, 19:2474-2488.

231. Buettner R, Mora LB, Jove R: Activated STAT signaling in human tumors provides novel molecular targets for therapeutic intervention. Clin Cancer Res 2002, 8:945-954.

232. Bromberg JF, Wrzeszczynska MH, Devgan G, Zhao Y, Pestell RG, Albanese C, Darnell JE Jr: Stat3 as an oncogene. Cell 1999, 98:295-303.

233. Fukada T, Ohtani T, Yoshida Y, Shirogane T, Nishida K, Nakajima K, Hibi M, Hirano T: STAT3 orchestrates contradictory signals in cytokine-induced G1 to S cell-cycle transition. EMBO J 1998, 17:6670-6677.

234. Niu G, Wright KL, Huang M, Song L, Haura E, Turkson J, Zhang S, Wang T, Sinibaldi D, Coppola D, Heller R, Ellis LM, Karras J, Bromberg J, Pardoll D, Jove R, Yu H: Constitutive Stat3 activity up-regulates VEGF expression and tumor angiogenesis. Oncogene 2002, 21:2000-2008.

235. Mori S, Matsuzaki K, Yoshida K, Furukawa F, Tahashi Y, Yamagata H, Sekimoto G, Seki T, Matsui H, Nishizawa M, Fujisawa J, Okazaki K: TGF-beta and HGF transmit the signals through JNK-dependent Smad2/3 phosphorylation at the linker regions. Oncogene 2004, 23:7416-7429.

236. Massague J: TGF-beta signal transduction. Annu Rev Biochem 1998, 67:753-791.

237. Massague J, Wotton D: Transcriptional control by the TGF-beta/Smad signaling system. EMBO J 2000, 19:1745-1754.

238. Grady WM: Transforming growth factor-beta, Smads, and cancer. Clin Cancer Res 2005, 11:3151-3154.

239. Meng XM, Chung AC, Lan HY: Role of the TGF-beta/BMP-7/Smad pathways in renal diseases. Clin Sci 2013, 124:243-254

240. Malhotra N, Kang J: SMAD regulatory networks construct a balanced immune system. Immunology 2013, 139:1-10.

241. Chappell WH, Steelman LS, Long JM, Kempf RC, Abrams SL, Franklin RA, Basecke J, Stivala F, Donia M, Fagone P, Malaponte G, Mazzarino MC, Nicoletti F, Libra M, Maksimovic-Ivanic D, Mijatovic S, Montalto G, Cervello M, Laidler P, Milella M, Tafuri A, Bonati A, Evangelisti C, Cocco L, Martelli AM, McCubrey JA: Ras/Raf/MEK/ERK and PI3K/PTEN/Akt/mTOR inhibitors: rationale and importance to inhibiting these pathways in human health. Oncotarget 2011, 2:135-164.

242. Maurer G, Tarkowski B, Baccarini M: Raf kinases in cancer-roles and therapeutic opportunities. Oncogene 2011, 30:3477-3488.

243. Roskoski R Jr: ERK1/2 MAP kinases: structure, function, and regulation. Pharmacol Res 2012, 66:105-143.

244. Ivanenkov YA, Balakin KV, Lavrovsky Y: Small molecule inhibitors of NF-kB and JAK/STAT signal transduction pathways as promising anti-inflammatory therapeutics. Mini Rev Med Chem 2011, 11:55-78.

245. Nagaraj NS, Datta PK: Targeting the transforming growth factor-beta signaling pathway in human cancer. Expert Opin Investig Drugs 2010, 19:77-91.

doi:10.1186/1477-7827-12-50

Cite this article as: Aznaurova et al:: Molecular aspects of development and regulation of endometriosis. Reproductive Biology and Endocrinology 2014 12:50.

\section{Submit your next manuscript to BioMed Central and take full advantage of:}

- Convenient online submission

- Thorough peer review

- No space constraints or color figure charges

- Immediate publication on acceptance

- Inclusion in PubMed, CAS, Scopus and Google Scholar

- Research which is freely available for redistribution

Submit your manuscript at www.biomedcentral.com/submit
C Biomed Central 